Original Research

\title{
Yeasts Isolated from Wheat Grain Can Suppress Fusarium Head Blight and Decrease Trichothecene Concentrations in Bread Wheat and Durum Wheat Grain
}

\author{
Urszula Wachowska ${ }^{1 *}$, Kinga Stuper-Szablewska ${ }^{2}$, Juliusz Perkowski² \\ ${ }^{1}$ University of Warmia and Mazury in Olsztyn, Department of Entomology, Phytopathology and Molecular Diagnostics \\ ${ }^{2}$ University of Life Sciences in Poznan, Department of Chemistry
}

Received: 14 November 2019

Accepted: 24 February 2020

\begin{abstract}
Fusarium head blight (FHB) is the most dangerous disease in all regions where bread wheat and durum wheat are grown, mostly due to grain contamination with trichothecenes produced by fungi of the genus Fusarium. Biological control of FHB with the use of yeast suspensions could pose a viable alternative to fungicides. The aim of this study was to perform in vitro selection of yeast isolates capable of inhibiting the development of FHB and reducing the concentrations of type A and type B trichothecenes in grain. In a field experiment, the inoculation of durum wheat spikes with Fusarium culmorum decreased grain yield by $9.13 \%$ and led to the highest accumulation of deoxynivalenol (DON) in grain at $11.704 \mathrm{mg} \mathrm{kg}^{-1}$. Isolates Candida sake Cs58, Rhodotorula glutinis $\operatorname{Rg} 64$ and Debaryomyces hansenii Dh53 most effectively inhibited the decline in durum wheat yield. Biological treatments induced a 10-fold decrease in the DON content of inoculated grain. Spike inoculation with F. culmorum decreased bread wheat yield by $19.88 \%$. The isolate Aureobasidium pullulans Ap24 was most effective in decreasing FHB symptoms, whereas the isolate D. hansenii Dh53 reduced DON concentration by 11.33 -fold in inoculated grain and decreased nivalenol concentration by 18.12-fold in the grain of noninoculated bread wheat.
\end{abstract}

Keywords: Fusarium culmorum, biological protection, Aureobasidium, Debaryomyces

\section{Introduction}

Durum wheat (Triticum turgidum L. spp. durum) and bread wheat (Triticum aestivum L. spp. aestivum)

*e-mail: urszula.wachowska@uwm.edu.pl

are important small grain cereals that are produced for human consumption. In 2017, the ten leading wheat producing countries were China, India, Russia, the USA, France, Australia, Canada, Pakistan, Ukraine and Germany. In Poland, bread wheat is grown on 2.38 million hectares and durum wheat is cultivated in southern Poland on around 2,200 hectares [1]. Tetraploid durum wheat and hexaploid bread wheat are 
susceptible to colonization by Fusarium fungi causing Fusarium head blight (FHB). However, due to their different origin, wheat cultivar differ in their resistance against initial infection (type I) and resistance against fungal spread within a spike (type II) [2]. The severity of FHB epidemics is affected not only by wheat cultivar and weather conditions but also by the structure of the Fusarium species complex. Fusarium graminearum sensu stricto is the most common species. Other Fusarium species have also been frequently reported, including $F$. avenaceum, F. culmorum, F. poae, $F$. langsethiae and $F$. sporotrichioides [3, 4].

Fusarium head blight (FHB) significantly decreases grain yields and lowers the quality of grain through contamination with mycotoxins, including trichothecenes [5]. Type B trichothecenes (deoxynivalenol (DON), 3-acetyl-deoxynivalenol (3ADON), 15-acetyl-deoxynivalenol (15ADON) and nivalenol (NIV) are produced mainly by $F$. graminearum and $F$. culmorum and are among the most frequently identified mycotoxins in cereal grain. In Central Europe, DON concentration in durum wheat grain was determined in the range of $116.94 \mu \mathrm{g} \mathrm{kg}^{-1}$ to $10.88 \mu \mathrm{g} / \mathrm{g}$, subject to cultivar and weather conditions $[6,7]$. In the discussed region, the average DON content of $T$. aestivum grain ranged from 140.2 to $210 \mu \mathrm{g} \mathrm{kg}^{-1}$ in non-inoculated grain [8], and the highest concentration of DON was determined at $11650 \mu \mathrm{g} \mathrm{kg}^{-1}$ in grain inoculated with $F$. culmorum [9]. Apart from their adverse effects on plants [10], type B trichothecenes disrupt gut homeostasis, and compromise neuroendocrine function and immunity of animals [Table 1, 10-13]. The less frequently detected T-2 toxin, a type A trichothecene, is produced by, among others, F. sporotrichioides and F. poae [14]. Type A trichothecenes also include scirpentriol (STO), T-2 tetraol, T-2 triol, diacetoxyscirpenol (DAS) and HT-2. In a study by Stuper and Perkowski [15], STO was the most frequently identified type A trichothecene colonizing bread wheat grain in a concentration range of $0.001-0.042 \mathrm{mg} \mathrm{kg}^{-1}$. Relating toxicity of individual trichothecenes based on any of these classification systems is not always straightforward [Table 1, 16]. The synergistic effects of several trichothecenes are greater than those exerted by individual trichothecenes [17, 18]. Type A trichothecenes such as DAS and T-2 toxin are generally more cytotoxic than type B trichothecenes such as DON [19]. Animal toxicity increases with increasing oxygenation of EPT [20]. A test of Fusarium trichothecenes on the model plant system Chlamydomonas revealed that both type A and type B C-3 acetylated trichothecenes were much less toxic than the corresponding C-3 hydroxyl trichothecenes [21].

In line with the integrated pest management strategy introduced by the European Union [22], crop producers should attempt to control Fusarium fungi with the use of alternatives, including biological, methods [23-26]. Alternative approaches can be used in combination with fungicides which are not always effective in controlling FHB due to the rapid spread of the disease and variations in the sensitivity of Fusarium species to these chemical control agents [27]. Safe mycotoxin levels have been set for wheat grain to protect the consumers' health. According to Commission Regulation (EC) No. 1881/2006 of 19 December 2006 and Commission Recommendation of 27 March 2013 [28, 29], the maximum concentrations of DON in unprocessed wheat grain are set at $1250 \mu \mathrm{g} \mathrm{kg}^{-1}$ for T. aestivum and $1750 \mu \mathrm{g} \mathrm{kg}^{-1}$ for $T$. durum, and the total content of T-2 toxin and HT-2 toxin may not exceed $100 \mu \mathrm{g} \mathrm{kg}^{-1}$ [30].

Yeasts are ubiquitous on cereal kernels, and they far more abundant fungi of the genus Fusarium [31, 32]. The role played by yeasts in agroecosystems and their usefulness for inhibiting the development of Fusarium pathogens through antibiosis and competition during the growing season have been widely researched [32-35]. Yeasts are also capable of biotransforming trichothecenes into less toxic compounds [36]. Yeasts can potentially be used for reducing trichothecene contamination of wheat grain. The aim of this study was to perform in vitro selection of yeast isolates obtained from wheat grain, capable of inhibiting the development of Fusarium culmorum: Aureobasidium pullulans, Candida sake, C. albicans, Debaryomyces hansenii, Metschnikowia pulcherrima and Rhodotorula glutinis. Active yeast isolates were evaluated under field conditions for their ability to alleviate the symptoms of FHB in bread wheat and durum wheat spikes inoculated with F. culmorum. Wheat spikes were analyzed to determine: (1) the severity of FHB symptoms, (2) grain yield, (3) grain contamination with fungi of the genus Fusarium, (4) content of type A and B trichothecenes in grain. The application of yeast in biological protection treatments against FHB in bread wheat has been previously studied by, among others, Schisler et al. $[25,26]$ and Wachowska et al. [37]. The effectiveness of biological protection methods against Fusarium pathogens in durum wheat has been evaluated by very few studies [7].

\section{Experimental}

\section{Yeast Isolation}

Yeasts were isolated from the grain of winter wheat cv. Bogatka according to a previously described method [37]. Yeasts were washed off from grain by shaking randomly selected kernels in $250 \mathrm{~cm}^{3}$ flasks containing $90 \mathrm{~cm}^{3}$ of sterile water (Elpin+ $378 \mathrm{~S}$ Shaker Table, Poland). The resulting fungal suspensions were transferred to Petri dishes. Selective Martin's medium [38] cooled to $42^{\circ} \mathrm{C}$ was poured into the plates. Pure yeast cultures grown on potato dextrose agar (PDA, Merck, Poland) were cultured at $24^{\circ} \mathrm{C}$ for $48 \mathrm{~h}$ (En 120 incubator, Poland). 
Table 1. Characteristics of type A and B trichothecenes.

\begin{tabular}{|c|c|c|c|c|c|}
\hline $\begin{array}{l}\text { Trichothecene } \\
\text { A compound }\end{array}$ & $\begin{array}{l}\text { Chemical } \\
\text { structure }\end{array}$ & Activity & $\begin{array}{l}\text { Trichothecene } \\
\text { B compound }\end{array}$ & $\begin{array}{l}\text { Chemical } \\
\text { structure }\end{array}$ & Activity \\
\hline T-2 Tetraol & & $\begin{array}{l}\text { Potential endocrine } \\
\text { disrupting } \\
\text { compound [13] }\end{array}$ & DON & & $\begin{array}{l}\text { Phytotoxic, affect } \\
\text { astrointestinal homeostasis, } \\
\text { growth, neuroendocrine } \\
\text { function, and immunity } \\
\text { of animals [10] }\end{array}$ \\
\hline HT-2-toxin & & $\begin{array}{c}\text { Potential } \\
\text { immunosuppressive } \\
\text { agent }[11]\end{array}$ & $3 \mathrm{ADON}$ & & $\begin{array}{c}\text { Gastrointestinal effects: } \\
\text { ulceration or bleeding from } \\
\text { small intestine, hypermotility, } \\
\text { diarrhea [19] }\end{array}$ \\
\hline STO & & Hepatotoxicity [75] & FUS-X & & $\begin{array}{l}\text { Potential immunosuppressive } \\
\text { agent [11] }\end{array}$ \\
\hline DAS & & Hepatotoxicity [76] & NIV & & Potential nematicide [12] \\
\hline
\end{tabular}

STO scirpentriol, DAS - diacetoxyscirpenol, DON - deoxynivalenol, 3ADON - 3-acetyl-deoxynivalenol, FUS-X - fusarenon X, NIV - nivalenol.

Yeast Identification

Selected isolates were identified based on their morphological features and the shape and size of budding cells, pseudofilaments and chlamydospores [39]. Yeast DNA was extracted with the DNA Genomic Mini AX Yeast Kit (A\&A Biotechnology, Poland). The fragment containing ITS $1,5.8 \mathrm{~S}$ and ITS 2 rDNA was amplified with specific ITS5 primers (F) GTATCGGACGGAGATCCAGC and ITS4 primers (R) TTGCTCAGTGCATTG TCGG [26] in the FailSafe PCR system (Epicentre, Poland). The electrophoresis of amplification products was carried out in $1 \%$ agarose gel (Prona, Poland) with the addition of Midori Green (ABO, Poland) in TBE buffer (Sigma, Poland). PCR products were sequenced by the Institute of Biophysics and Biochemistry of the Polish Academy of Sciences in Warsaw. Sequence similarity was determined in the BLAST program in the NCBI database [40].

\section{Isolate Accession Numbers}

The ITS1, 5.8S and ITS2 rDNA sequences of 20 isolates were deposited in GenBank under the following accession numbers: Aureobasidium pullulans - KX444657, KX44458, KX444670, KX424381-
KX424384, Candida sake - KX444660, C. albicans - KX444661, Debaryomyces hansenii - KX444669, KX444668, Metschnikowia pulcherrima - KX424389, Rhodotorula glutinis - KX424385-KX424388, KX444653-KX444655.

In vitro Selection of Yeast Isolates Inhibiting the Development of Fusarium culmorum Colonies

The activity of yeast isolates was evaluated on Petri plates filled with PDA to select isolates capable of inhibiting the growth of Fusarium fungi (Merck, Poland) (Table 2). Agar discs with a diameter of $5 \mathrm{~mm}$, overgrown with $F$. culmorum filaments, were placed in the center of Petri plates with a diameter of $9 \mathrm{~cm}$. Isolates of A. pullulans, C. sake, C. albicans, $D$. hansenii, M. pulcherrima and Rh. glutinis cultured for 48 hours were placed on Petri plates at a distance of $2 \mathrm{~cm}$ from agar discs. After four days of incubation at $24^{\circ} \mathrm{C}$ (En 120 incubator, Poland), the isolates were photographed (Sony Alpha DSLR-A330, Japan), and the images were transferred to a PC (Integrit, Poland). The ellipticity index of a pathogenic colony was calculated by dividing the smaller diameter by the larger diameter. The area of the pathogenic colony was measured in the ImageJ 1.49 program [41]. Yeast isolates which 
Table 2. Characteristic features of epiphytes and endophytes isolated from wheat and used for screening tests by dual culture with Fusarium culmorum.

\begin{tabular}{|c|c|c|c|c|c|c|}
\hline \multirow[b]{2}{*}{ Isolate } & \multirow[b]{2}{*}{ Origin $^{A}$} & \multirow[b]{2}{*}{ Species } & \multicolumn{4}{|c|}{ Dual culture inhibition } \\
\hline & & & $\begin{array}{l}\text { Ellipticity index } \\
\qquad( \pm \text { SE })\end{array}$ & $\begin{array}{l}\text { Isolate } \\
\text { activity }{ }^{B}\end{array}$ & $\begin{array}{c}\% \text { inhibition of } \\
\text { colony growth }( \pm \mathrm{SE})\end{array}$ & $\begin{array}{l}\text { Isolate } \\
\text { activity }{ }^{\mathrm{C}}\end{array}$ \\
\hline $\mathrm{Ca} 6 \mathrm{a}$ & $\mathrm{En} / \mathrm{NC}$ & Candida albicans & $0.99^{\mathrm{a}}( \pm 0.010)$ & NA & $34.05^{\mathrm{b}-\mathrm{e}}( \pm 3.556)$ & NR \\
\hline $\mathrm{Ca} 6$ & $\mathrm{En} / \mathrm{NC}$ & Candida albicans & $0.79^{\mathrm{a}-\mathrm{o}}( \pm 0.113)$ & NA & $32.68^{\mathrm{cde}}( \pm 2.516)$ & NR \\
\hline $\mathrm{Ca} 4$ & $\mathrm{En} / \mathrm{NC}$ & Candida albicans & $0.57^{\mathrm{rs}}( \pm 0.023)$ & NA & $76.94^{\mathrm{abc}}( \pm 4.267)$ & NR \\
\hline Ca 5 & $\mathrm{En} / \mathrm{NC}$ & Candida albicans & $0.67^{1-\mathrm{s}}( \pm 0.162)$ & A & $80.95^{\mathrm{abc}}( \pm 8.717)$ & $\mathrm{R}$ \\
\hline Ca 3 & $\mathrm{En} / \mathrm{NC}$ & Candida albicans & $0.83^{\mathrm{a}-\mathrm{m}}( \pm 0.042)$ & NA & $85.98^{\mathrm{abc}}( \pm 1.680)$ & $\mathrm{R}$ \\
\hline $\mathrm{Ca} 2$ & $\mathrm{En} / \mathrm{NC}$ & Candida albicans & $0.84^{\mathrm{a}-\mathrm{n}}( \pm 0.025)$ & NA & $86.52^{\mathrm{abc}}( \pm 2.740)$ & $\mathrm{R}$ \\
\hline $\mathrm{Ca} 1$ & $\mathrm{En} / \mathrm{NC}$ & Candida albicans & $0.78^{\mathrm{b}-\mathrm{p}}( \pm 0.034)$ & NA & $88.00^{\mathrm{abc}}( \pm 0.537)$ & $\mathrm{R}$ \\
\hline Mp 13 & $\mathrm{EP} / \mathrm{E}$ & Metschnikowia pulcherrima & $0.76^{\mathrm{c}-\mathrm{s}}( \pm 0.070)$ & NA & $90.36^{\mathrm{a}}( \pm 0.055)$ & Z \\
\hline Mp 12 & $\mathrm{EP} / \mathrm{E}$ & Metschnikowia pulcherrima & $0.82^{\mathrm{a}-\mathrm{n}}( \pm 0.071)$ & NA & $89.89^{\mathrm{a}}( \pm 0.468)$ & $\mathrm{R}$ \\
\hline Mp 11 & $\mathrm{EP} / \mathrm{E}$ & Metschnikowia pulcherrima & $0.68^{\mathrm{k}-\mathrm{s}}( \pm 0.065)$ & NA & $87.19^{\mathrm{ab}}( \pm 2.231)$ & $\mathrm{R}$ \\
\hline Mp 10 & $\mathrm{EP} / \mathrm{E}$ & Metschnikowia pulcherrima & $0.62^{0-\mathrm{s}}( \pm 0.085)$ & A & $82.00^{\mathrm{abc}}( \pm 6.762)$ & $\mathrm{R}$ \\
\hline Mp 9 & $\mathrm{EP} / \mathrm{E}$ & Metschnikowia pulcherrima & $0.74^{\mathrm{e}-\mathrm{s}}( \pm 0.025)$ & NA & $87.88^{\mathrm{ab}}( \pm 0.061)$ & $\mathrm{R}$ \\
\hline Mp 8 & $\mathrm{En} / \mathrm{I}$ & Metschnikowia pulcherrima & $0.68^{1-\mathrm{s}}( \pm 0.056)$ & A & $88.27^{\mathrm{a}}( \pm 2.919)$ & $\mathrm{R}$ \\
\hline Mp 7 & $\mathrm{En} / \mathrm{I}$ & Metschnikowia pulcherrima & $0.73^{\mathrm{g}-\mathrm{s}}( \pm 0.040)$ & NA & $89.46^{\mathrm{a}}( \pm 1.032)$ & $\mathrm{R}$ \\
\hline $\mathrm{Ca} 14$ & $\mathrm{En} / \mathrm{I}$ & Candida albicans & $0.82^{\mathrm{a}-\mathrm{n}}( \pm 0.029)$ & NA & $46.19^{\mathrm{a}-\mathrm{e}}( \pm 19.597)$ & NR \\
\hline $\mathrm{Ca} 15$ & $\mathrm{En} / \mathrm{I}$ & Candida albicans & $0.94^{\mathrm{a}-\mathrm{f}}( \pm 0.032)$ & NA & $44.37^{\mathrm{a}-\mathrm{e}}( \pm 17.750)$ & NR \\
\hline Mp 21 & $\mathrm{En} / \mathrm{I}$ & Metschnikowia pulcherrima & $0.79^{\mathrm{a}-\mathrm{p}}( \pm 0.066)$ & NA & $91.18^{\mathrm{a}}( \pm 0.434)$ & Z \\
\hline Mp 20 & $\mathrm{En} / \mathrm{I}$ & Metschnikowia pulcherrima & $0.82^{\mathrm{a}-\mathrm{n}}( \pm 0.112)$ & NA & $83.89^{\mathrm{abc}}( \pm 3.725)$ & $\mathrm{R}$ \\
\hline Mp 19 & $\mathrm{En} / \mathrm{I}$ & Metschnikowia pulcherrima & $0.71^{\mathrm{i}-\mathrm{s}}( \pm 0.140)$ & NA & $76.19^{\mathrm{abc}}( \pm 6.080)$ & NR \\
\hline Mp 18 & $\mathrm{En} / \mathrm{I}$ & Metschnikowia pulcherrima & $0.74^{\mathrm{c}-\mathrm{s}}( \pm 0.006)$ & NA & $84.34^{\mathrm{abc}}( \pm 2.272)$ & $\mathrm{R}$ \\
\hline Mp 17 & $\mathrm{En} / \mathrm{I}$ & Metschnikowia pulcherrima & $0.84^{\mathrm{a}-\mathrm{n}}( \pm 0.059)$ & NA & $87.87^{\mathrm{ab}}( \pm 1.749)$ & $\mathrm{R}$ \\
\hline Mp 16 & $\mathrm{En} / \mathrm{I}$ & Metschnikowia pulcherrima & $0.94^{\mathrm{a}-\mathrm{f}}( \pm 0.028)$ & NA & $85.91^{\mathrm{abc}}( \pm 0.426)$ & $\mathrm{R}$ \\
\hline Ca 39 & $\mathrm{En} / \mathrm{I}$ & Candida albicans & $0.93^{\mathrm{a}-\mathrm{g}}( \pm 0.058)$ & NA & $18.47^{\mathrm{de}}( \pm 5.095)$ & NR \\
\hline $\mathrm{Ca} 40$ & $\mathrm{En} / \mathrm{I}$ & Candida albicans & $0.59^{\mathrm{prs}}( \pm 0.185)$ & NA & $54.07^{\mathrm{a}-\mathrm{e}}( \pm 6.128)$ & NR \\
\hline $\mathrm{Ca} 41$ & $\mathrm{En} / \mathrm{I}$ & Candida albicans & $0.84^{\mathrm{a}-\mathrm{n}}( \pm 0.043)$ & NA & $57.94^{\mathrm{a}-\mathrm{e}}( \pm 1.322)$ & NR \\
\hline $\mathrm{Ca} 42$ & $\mathrm{En} / \mathrm{I}$ & Candida albicans & $0.95^{\mathrm{abc}}( \pm 0.029)$ & NA & $67.96^{\mathrm{a}-\mathrm{e}}( \pm 0.358)$ & NR \\
\hline $\mathrm{Ca} 43$ & $\mathrm{En} / \mathrm{I}$ & Candida albicans & $0.83^{\mathrm{a}-\mathrm{n}}( \pm 0.004)$ & NA & $80.26^{\mathrm{abc}}( \pm 13.723)$ & $\mathrm{R}$ \\
\hline Cs 37 & $\mathrm{En} / \mathrm{I}$ & Candida sake & $0.93^{\mathrm{a}-\mathrm{f}}( \pm 0.003)$ & NA & $17.02^{\mathrm{c}}( \pm 10.673)$ & NR \\
\hline Cs 38 & $\mathrm{En} / \mathrm{I}$ & Candida sake & $0.94^{\mathrm{a}-\mathrm{e}}( \pm 0.036)$ & NA & $63.50^{\mathrm{a}-\mathrm{e}}( \pm 1.377)$ & NR \\
\hline $\mathrm{Ca} 39 \mathrm{a}$ & $\mathrm{En} / \mathrm{I}$ & Candida albicans & $0.74^{\mathrm{f}-\mathrm{s}}( \pm 0.165)$ & NA & $74.74^{\mathrm{abc}}( \pm 13.303)$ & NR \\
\hline $\mathrm{Ca} 40 \mathrm{a}$ & $\mathrm{En} / \mathrm{I}$ & Candida albicans & $0.95^{\mathrm{a}-\mathrm{e}}( \pm 0.011)$ & NA & $68.60^{\mathrm{a}-\mathrm{e}}( \pm 1.652)$ & NR \\
\hline Ap 36 & $\mathrm{En} / \mathrm{I}$ & Aureobasidium pullulans & $0.97^{\mathrm{ab}}( \pm 0.005)$ & NA & $63.01^{\mathrm{a}-\mathrm{e}}( \pm 10.934)$ & NR \\
\hline Cs $42 \mathrm{a}$ & $\mathrm{En} / \mathrm{I}$ & Candida sake & $0.90^{\mathrm{a}-\mathrm{d}}( \pm 0.063)$ & NA & $53.73^{\mathrm{a}-\mathrm{e}}( \pm 13.221)$ & NR \\
\hline Ap 22 & $\mathrm{En} / \mathrm{B}$ & Aureobasidium pullulans & $0.81^{\mathrm{a}-\mathrm{o}}( \pm 0.047)$ & NA & $90.26^{\mathrm{a}}( \pm 0.241)$ & $\mathrm{Z}$ \\
\hline Ap 23 & $\mathrm{En} / \mathrm{B}$ & Aureobasidium pullulans & $0.74^{\mathrm{d}-\mathrm{s}}( \pm 0.037)$ & NA & $88.87^{\mathrm{ab}}( \pm 0.110)$ & $\mathrm{R}$ \\
\hline Ap 24 & $\mathrm{En} / \mathrm{B}$ & Aureobasidium pullulans & $0.79^{\mathrm{a}-\mathrm{o}}( \pm 0.003)$ & NA & $90.45^{\mathrm{a}}( \pm 0.364)$ & Z \\
\hline Ap 25 & $\mathrm{En} / \mathrm{B}$ & Aureobasidium pullulans & $0.89^{\mathrm{a}-\mathrm{k}}( \pm 0.068)$ & NA & $91.76^{\mathrm{a}}( \pm 0.633)$ & $\mathrm{Z}$ \\
\hline
\end{tabular}


Table 2. Continued.

\begin{tabular}{|c|c|c|c|c|c|c|}
\hline \multirow[b]{2}{*}{ Isolate } & \multirow[b]{2}{*}{ Origin $^{\mathrm{A}}$} & \multirow[b]{2}{*}{ Species } & \multicolumn{4}{|c|}{ Dual culture inhibition } \\
\hline & & & $\begin{array}{l}\text { Ellipticity index } \\
( \pm \mathrm{SE})\end{array}$ & $\begin{array}{c}\text { Isolate } \\
\text { activity }{ }^{\mathrm{B}}\end{array}$ & $\begin{array}{c}\% \text { inhibition of } \\
\text { colony growth }( \pm \mathrm{SE})\end{array}$ & $\begin{array}{c}\text { Isolate } \\
\text { activity }\end{array}$ \\
\hline Ap 26 & $\mathrm{En} / \mathrm{B}$ & Aureobasidium pullulans & $0.85^{\mathrm{a}-\mathrm{m}}( \pm 0.021)$ & NA & $91.37^{\mathrm{a}}( \pm 1.693)$ & Z \\
\hline Ap 27 & $\mathrm{En} / \mathrm{B}$ & Aureobasidium pullulans & $0.72^{\mathrm{h}-\mathrm{s}}( \pm 0.112)$ & NA & $85.50^{\mathrm{abc}}( \pm 0.378)$ & $\mathrm{R}$ \\
\hline Ap 29 & $\mathrm{En} / \mathrm{B}$ & Aureobasidium pullulans & $0.78^{\mathrm{a}-\mathrm{p}}( \pm 0.009)$ & NA & $88.56^{\mathrm{a}}( \pm 1.198)$ & $\mathrm{R}$ \\
\hline Ap 30 & $\mathrm{En} / \mathrm{B}$ & Aureobasidium pullulans & $0.79^{\mathrm{a}-\mathrm{o}}( \pm 0.032)$ & NA & $87.62^{\mathrm{ab}}( \pm 2.795)$ & $\mathrm{R}$ \\
\hline Dh 33 & $\mathrm{En} / \mathrm{B}$ & Debaryomyces hansenii & $0.69^{\mathrm{j}-\mathrm{s}}( \pm 0.143)$ & A & $81.66^{\mathrm{abc}}( \pm 7.230)$ & $\mathrm{R}$ \\
\hline Ap 34 & $\mathrm{En} / \mathrm{B}$ & Aureobasidium pullulans & $0.71^{\mathrm{i}-\mathrm{s}}( \pm 0.012)$ & NA & $87.67^{\mathrm{bc}}( \pm 3.649)$ & $\mathrm{R}$ \\
\hline Ap 35 & $\mathrm{En} / \mathrm{B}$ & Aureobasidium pullulans & $0.71^{\mathrm{i}-\mathrm{s}}( \pm 0.087)$ & NA & $85.12^{\mathrm{abc}}( \pm 4.957)$ & $\mathrm{R}$ \\
\hline Dh 50 & $\mathrm{EP} / \mathrm{NC}$ & Debaryomyces hansenii & $0.65^{\mathrm{m}-\mathrm{s}}( \pm 0.042)$ & A & $62.87^{\mathrm{a}-\mathrm{e}}( \pm 16.856)$ & NR \\
\hline Dh 51 & $\mathrm{EP} / \mathrm{NC}$ & Debaryomyces hansenii & $0.56^{\mathrm{s}}( \pm 0.076)$ & A & $65.08^{\mathrm{a}-\mathrm{e}}( \pm 9.158)$ & NR \\
\hline Dh 52 & $\mathrm{EP} / \mathrm{NC}$ & Debaryomyces hansenii & $0.70^{\mathrm{i}-\mathrm{s}}( \pm 0.003)$ & NA & $83.54^{\mathrm{abc}}( \pm 2.327)$ & $\mathrm{R}$ \\
\hline Dh 53 & $\mathrm{EP} / \mathrm{E}$ & Debaryomyces hansenii & $0.56^{\mathrm{s}}( \pm 0.076)$ & A & $76.13^{\mathrm{abc}}( \pm 11.313)$ & NR \\
\hline Dh 54 & $\mathrm{EP} / \mathrm{E}$ & Debaryomyces hansenii & $0.74^{\mathrm{d}-\mathrm{s}}( \pm 0.184)$ & NA & $71.47^{\mathrm{abc}}( \pm 7.065)$ & NR \\
\hline Dh 55 & $\mathrm{EP} / \mathrm{E}$ & Debaryomyces hansenii & $0.79^{\mathrm{a}-\mathrm{o}}( \pm 0.024)$ & NA & $80.91^{\mathrm{abc}}( \pm 0.578)$ & $\mathrm{R}$ \\
\hline Dh 56 & $\mathrm{EP} / \mathrm{E}$ & Debaryomyces hansenii & $0.77^{\mathrm{a}-\mathrm{r}}\left( \pm 0.065^{)}\right.$ & NA & $81.71^{\mathrm{abc}}( \pm 1.542)$ & $\mathrm{R}$ \\
\hline Dh 57 & $\mathrm{EP} / \mathrm{E}$ & Debaryomyces hansenii & $0.77^{\mathrm{c}-\mathrm{r}}( \pm 0.145)$ & NA & $82.37^{\mathrm{abc}}( \pm 2.203)$ & $\mathrm{R}$ \\
\hline Cs 58 & $\mathrm{EP} / \mathrm{E}$ & Candida sake & $0.70^{\mathrm{j}-\mathrm{s}}( \pm 0.035)$ & NA & $80.45^{\mathrm{abc}}( \pm 1.611)$ & $\mathrm{R}$ \\
\hline Cs 59 & $\mathrm{EP} / \mathrm{E}$ & Candida sake & $0.73^{\mathrm{g}-\mathrm{s}}( \pm 0.038)$ & NA & $81.50^{\mathrm{abc}}( \pm 3.319)$ & $\mathrm{R}$ \\
\hline Ap 60 & $\mathrm{EP} / \mathrm{I}$ & Aureobasidium pullulans & $0.74^{\mathrm{e}-\mathrm{s}}( \pm 0.001)$ & NA & $88.82^{\mathrm{a}}( \pm 1.356)$ & $\mathrm{R}$ \\
\hline Ap 61 & $\mathrm{EP} / \mathrm{I}$ & Aureobasidium pullulans & $0.76^{\mathrm{c}-\mathrm{s}}( \pm 0.025)$ & NA & $89.91^{\mathrm{a}}( \pm 1.611)$ & $\mathrm{R}$ \\
\hline Ap 62 & $\mathrm{EP} / \mathrm{I}$ & Aureobasidium pullulans & $0.75^{\mathrm{c}-\mathrm{s}}( \pm 0.024)$ & NA & $89.22^{\mathrm{a}}( \pm 2.974)$ & $\mathrm{R}$ \\
\hline Dh 63 & $\mathrm{EP} / \mathrm{I}$ & Debaryomyces hansenii & $0.57^{\mathrm{rs}}( \pm 0.036)$ & A & $65.82^{\mathrm{a}-\mathrm{e}}( \pm 4.214)$ & NR \\
\hline $\operatorname{Rg} 64$ & $\mathrm{EP} / \mathrm{I}$ & Rhodotorula glutinis & $0.84^{\mathrm{a}-\mathrm{n}}( \pm 0.147)$ & NA & $46.81^{\mathrm{a}-\mathrm{e}}( \pm 27.406)$ & NR \\
\hline $\operatorname{Rg} 65$ & $\mathrm{EP} / \mathrm{I}$ & Rhodotorula glutinis & $0.70^{\mathrm{i}-\mathrm{s}}( \pm 0.011)$ & NA & $80.59^{\mathrm{a}-\mathrm{e}}( \pm 25.677)$ & $\mathrm{R}$ \\
\hline Cs 66 & $\mathrm{EP} / \mathrm{I}$ & Candida sake & $0.87^{\mathrm{a}-1}( \pm 0.019)$ & NA & $83.87^{\mathrm{abc}}( \pm 1.666)$ & $\mathrm{R}$ \\
\hline Dh 67 & $\mathrm{EP} / \mathrm{I}$ & Debaryomyces hansenii & $0.92^{\mathrm{a}-\mathrm{g}}( \pm 0.002)$ & NA & $80.65^{\mathrm{abc}}( \pm 1.032)$ & $\mathrm{R}$ \\
\hline Cs 68 & $\mathrm{EP} / \mathrm{I}$ & Candida sake & $0.87^{\mathrm{a}-1}( \pm 0.092)$ & NA & $85.78^{\mathrm{abc}}( \pm 0.577)$ & $\mathrm{R}$ \\
\hline Ap 70 & $\mathrm{EP} / \mathrm{I}$ & Aureobasidium pullulans & $0.64^{\mathrm{n}-\mathrm{s}}( \pm 0.027)$ & A & $75.67^{\mathrm{abc}}\left( \pm 8.125^{5}\right)$ & NR \\
\hline Dh 69 & $\mathrm{EP} / \mathrm{I}$ & Debaryomyces hansenii & $0.76^{\mathrm{c}-\mathrm{s}}( \pm 0.056)$ & NA & $89.28^{\mathrm{a}}( \pm 2.534)$ & $\mathrm{R}$ \\
\hline Dh 71 & $\mathrm{EP} / \mathrm{I}$ & Debaryomyces hansenii & $0.67^{1-\mathrm{s}}( \pm 0.042)$ & A & $73.85^{\mathrm{abc}}( \pm 5.247)$ & NR \\
\hline Ap 73 & $\mathrm{EP} / \mathrm{B}$ & Aureobasidium pullulans & $0.91^{\mathrm{a}-\mathrm{i}}( \pm 0.056)$ & NA & $90.13^{\mathrm{a}}( \pm 1.315)$ & Z \\
\hline Ap 74 & $\mathrm{EP} / \mathrm{B}$ & Aureobasidium pullulans & $0.76^{\mathrm{c}-\mathrm{s}}( \pm 0.178)$ & A & $86.16^{\mathrm{abc}}( \pm 3.213)$ & $\mathrm{R}$ \\
\hline Ap 75 & $\mathrm{EP} / \mathrm{B}$ & Aureobasidium pullulans & $0.81^{\mathrm{a}-\mathrm{n}}( \pm 0.026)$ & NA & $90.21^{\mathrm{a}}( \pm 1.308)$ & Z \\
\hline Ap 76 & $\mathrm{EP} / \mathrm{B}$ & Aureobasidium pullulans & $0.83^{\mathrm{a}-\mathrm{n}}( \pm 0.086)$ & NA & $88.32^{\mathrm{a}}( \pm 0.661)$ & $\mathrm{R}$ \\
\hline Ap 77 & $\mathrm{EP} / \mathrm{B}$ & Aureobasidium pullulans & $0.82^{\mathrm{a}-\mathrm{n}}( \pm 0.014)$ & NA & $85.37^{\mathrm{abc}}( \pm 0.247)$ & $\mathrm{R}$ \\
\hline Ap 78 & $\mathrm{EP} / \mathrm{B}$ & Aureobasidium pullulans & $0.79^{\mathrm{a}-\mathrm{p}}( \pm 0.024)$ & NA & $88.18^{\mathrm{ab}}( \pm 0.358)$ & $\mathrm{R}$ \\
\hline Dh 79 & $\mathrm{EP} / \mathrm{E}$ & Debaryomyces hansenii & $0.85^{\mathrm{a}-\mathrm{m}}( \pm 0.045)$ & NA & $80.25^{\mathrm{abc}}( \pm 0.082)$ & $\mathrm{R}$ \\
\hline Dh 80 & $\mathrm{EP} / \mathrm{E}$ & Debaryomyces hansenii & $0.79^{\mathrm{a}-\mathrm{p}}( \pm 0.045)$ & NA & $81.47^{\mathrm{abc}}( \pm 3.649)$ & $\mathrm{R}$ \\
\hline Dh 81 & $\mathrm{EP} / \mathrm{E}$ & Debaryomyces hansenii & $0.74^{\mathrm{f}-\mathrm{s}}( \pm 0.047)$ & NA & $83.00^{\mathrm{abc}}( \pm 2.217)$ & $\mathrm{R}$ \\
\hline
\end{tabular}


Table 2. Continued.

\begin{tabular}{|c|c|c|c|c|c|c|}
\hline Ap 82 & EP/E & Aureobasidium pullulans & $0.68^{1-\mathrm{s}}( \pm 0.082)$ & $\mathrm{A}$ & $81.41^{\mathrm{abc}}( \pm 6.410)$ & $\mathrm{R}$ \\
\hline Ap 83 & $\mathrm{EP} / \mathrm{E}$ & Aureobasidium pullulans & $0.77^{\mathrm{a}-\mathrm{p}}( \pm 0.034)$ & $\mathrm{NA}$ & $88.00^{\mathrm{abc}}( \pm 0.537)$ & $\mathrm{R}$ \\
\hline
\end{tabular}

A - EN - endophytes, EP- epiphytes, NC - grain from unprotected plants, I - grain from plants subjected to intensive fungicide protection, $\mathrm{E}$ - grain from plants subjected to extensive fungicide protection, $\mathrm{B}$ - grain from plants subjected to biological protection. ${ }^{\text {B }} \mathrm{A}$ - isolates which induced significant changes in the shape of Fusarium culmorum colonies (ellipticity index $<=0.70$ ) in dual cultures were regarded as active; (NA) the remaining isolates were not active.

C - Z - isolates which decreased colony area by at least $90 \%, \mathrm{R}$ - isolates which decreased colony area by $80-90 \%$, NR - isolates which inhibited colony growth by less than $80 \%$.

Values that did not differ significantly in the SNK test $(\mathrm{p}<0.001)$ are marked with the same letters in columns.

SE-standard error

inhibited the growth of pathogenic fungi by minimum $90 \%$ relative to the area of $F$. culmorum colonies growing without yeast isolates and yeast isolates which decreased the ellipticity index of pathogenic colonies to 0.70 or below were regarded as highly active.

\section{Field Experiment}

Field-plot experiment 1 with biological, fungicidal and integrated crop protection was carried out in

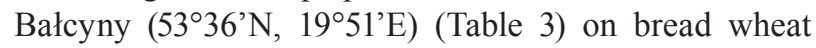
(cv. Skagen, resistant to infections caused by Fusarium spp.) and durum wheat (cv. Komnata, highly susceptible to infections caused by Fusarium spp.) [42, 43]. The experiment had a randomized block design with three replications. Plot area was $15 \mathrm{~m}^{2}$. In biological control treatments (Biol 1), the following yeast suspensions were sprayed on wheat plants during three growth stages: C. sake Cs58 - first node detectable at least $1 \mathrm{~cm}$ above the tillering node (BBCH 31) [24], Rh. glutinis Rg64 - middle of heading (BBCH 55), and D. hansenii Dh53 - full flowering (BBCH 65) (Table 3). In fungicide treatments (Fung1), the following fungicides were applied during three growth stages: a commercial mixture of fenpropimorph, metrafenone and epoxiconazole $\left(1.5 \mathrm{dm}^{3}\right.$ per ha, concentration of fungicide $0.25 \%$ ) in stage $\mathrm{BBCH} 31$, a commercial mixture of prothioconazole and fluoxastrobin $\left(1 \mathrm{dm}^{3}\right.$ per ha) in stage $\mathrm{BBCH} 55$, and tebuconazole $\left(1 \mathrm{dm}^{3}\right.$ per ha, concentration of fungicide $0.17 \%$ ) in the watery ripe stage $(\mathrm{BBCH}$ 71). Integrated crop protection (Integ1) involved three treatments: laminarin resistance inducer $\left(1 \mathrm{dm}^{3}\right.$ per ha, the concentration of product $0.17 \%$ ) in stage $\mathrm{BBCH} 31$, a commercial mixture of prothioconazole and fluoxastrobin $\left(1 \mathrm{dm}^{3}\right.$ per ha, concentration of fungicide $0.17 \%$ ) in stage $\mathrm{BBCH} 55$, and a suspension of $D$. hansenii Dh50 cells in stage BBCH 65 (Table 3). The experiment was conducted in three replications. Unprotected plants were the control.

Field-plot experiment 2 involving integrated (Integ 2) and chemical protection (Fung 2, Fung 3) treatments was carried out in Bałdy in north-eastern

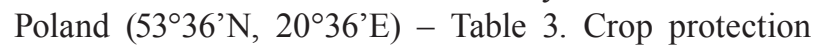
treatments composed of azole (Fung 2, Fung 3, Integ 2), morpholine (Integ 2), benzimidazole (Fung 2) and strobilurin (Fung 2, Fung 3). Fungicides were applied twice (Fung 3, Integ 2) or three times (Fung 2) to winter wheat (T. aestivum L., cv. Bogatka) sown in plots with an area of $20 \mathrm{~m}^{2}$ each in growth stages BBCH 31, BBCH 55 and BBCH 71 (Table 3). The experiment had a randomized block design. The biological treatment involving a suspension of D. hansenii Dh53 cells (Integ 2) was performed at full flowering (BBCH 65). The experiment was conducted in four replications. Unprotected plants were the control.

Field-plot experiment 3 with biological crop protection was performed in Bałdy (N 53 ${ }^{\circ} 36^{\prime}$, E $20^{\circ}$ 36'). Winter wheat (T. aestivum L., cv. Tonacja) was sown in plots with an area of $1 \mathrm{~m}^{2}$ each. The experiment had a randomized block design with three replications. Suspensions of $A$. pullulans Ap24 or D. hansenii Dh53 cells were applied three times in stages BBCH 31, $\mathrm{BBCH} 55$ and $\mathrm{BBCH} 65$ (Table 3). Unprotected plants were the control.

\section{Preparation of Yeast Isolates for Crop Protection Treatments}

Five yeast isolates, A. pullulans Ap24 (NCBI GenBank accession number KX444670), D. hansenii Dh53 (KX444669), D. hansenii Dh50 (KX444668), C. sake $\mathrm{Cs} 58$ (KX444660) and Rh. glutinis Rg64 (KX424386) were used in biological protection treatments. Yeast isolates were incubated (En 120 incubator, Poland) on PDA (Merck, Poland) at $24^{\circ} \mathrm{C}$. Yeasts were rinsed off with $5 \mathrm{~cm}^{3}$ of sterile water (per plate) with the use of an inoculation loop into $1 \mathrm{dm}^{3}$ flasks. Yeast suspensions were brought to a concentration of $10^{6}-10^{7}$ cells in $1 \mathrm{~cm}^{3}$ of water (Thoma cell counting chamber, Fein-Optik, Germany). Backpack sprayers with $12 \mathrm{dm}^{3}$ tank capacity (Marolex Titan 12, Poland) were filled with $1 \mathrm{dm}^{3}$ of the yeast suspension each, diluted with $9 \mathrm{dm}^{3}$ of water, and they were used to spray plots with an area of $15-20 \mathrm{~m}^{2}$. Plots with an area of $1 \mathrm{~m}^{2}$ were sprayed with a manual sprayer (1.5 $\mathrm{dm}^{3}$, Marolex Master, Poland) containing $250 \mathrm{~cm}^{3}$ of the yeast suspension and $750 \mathrm{~cm}^{3}$ of water. Biological treatments were performed on windless days in the afternoon. 
Table 3. Treatments applied to winter wheat.

\begin{tabular}{|c|c|c|c|c|}
\hline & BBCH 31 & BBCH 55 & BBCH 65 & BBCH 71 \\
\hline Treatment & $\begin{array}{c}\text { (First node at least } 1 \mathrm{~cm} \text { above } \\
\text { tillering node) }\end{array}$ & (Middle of heading) & (Full flowering) & $\begin{array}{l}\text { (Second fruit } \\
\text { fall) }\end{array}$ \\
\hline & \multicolumn{4}{|c|}{ Experiment 1 (Bałcyny) } \\
\hline Fung 1 & $\begin{array}{l}\text { Fenpropimorph, metrafenone, } \\
\text { epoxyconazole }{ }^{1}\left(0.25 \%, 1.5 \mathrm{dm}^{3}\right. \\
\text { per ha) }\end{array}$ & $\begin{array}{l}\text { Prothioconazole, fluoxastrobin }{ }^{2} \\
\qquad\left(0.17 \%, 1 \mathrm{dm}^{3} \text { per ha }\right)\end{array}$ & No treatment & Tebuconazole ${ }^{3}$ \\
\hline Integ 1 & Laminarin $^{4}\left(0.17 \%, 1 \mathrm{dm}^{3}\right.$ per ha $)$ & $\begin{array}{l}\text { Prothioconazole, fluoxastrobin }{ }^{2} \\
\qquad\left(0.17 \%, 1 \mathrm{dm}^{3} \text { per ha }\right)\end{array}$ & $\begin{array}{l}\text { Debaryomyces hansenii Dh50 } \\
\text { KX444668 }\end{array}$ & No treatment \\
\hline \multirow[t]{2}{*}{ Biol 1} & Candida sake Cs58 KX444660 & $\begin{array}{c}\text { Rhodotorula glutinis } \operatorname{Rg} 64 \\
\text { KX424386 }\end{array}$ & $\begin{array}{c}\text { Debaryomyces hansenii Dh53 } \\
\text { KX444669 }\end{array}$ & No treatment \\
\hline & \multicolumn{4}{|c|}{ Experiment 2 (Bałdy) } \\
\hline Integ 2 & $\begin{array}{l}\text { Fenpropimorph, epoxiconazole } \\
\quad\left(0.17 \%, 1 \mathrm{dm}^{3} \text { per ha }\right)\end{array}$ & Propiconazole ${ }^{6}\left(1 \mathrm{dm}^{3}\right.$ per ha $)$ & $\begin{array}{c}\text { Debaryomyces hansenii Dh53 } \\
\text { KX444669 }\end{array}$ & No treatment \\
\hline Fung 2 & Chlorothalonile $^{7}$ & $\begin{array}{l}\text { Epoxiconazole, piraclostrobin } \\
\left(0.25 \%, 1.5 \mathrm{dm}^{3} \text { per ha }\right)\end{array}$ & No treatment & Tebuconazole ${ }^{3}$ \\
\hline \multirow[t]{2}{*}{ Fung 3} & No treatment & $\begin{array}{l}\text { Epoxiconazole, piraclostrobin } \\
\left(0.25 \%, 1.5 \mathrm{dm}^{3} \text { per ha }\right)\end{array}$ & No treatment & Tebuconazole ${ }^{3}$ \\
\hline & \multicolumn{4}{|c|}{ Experiment 3 (Bałdy) } \\
\hline Biol 2 & $\begin{array}{l}\text { Aureobasidium pullulans Ap24 } \\
\text { KX444670 }\end{array}$ & $\begin{array}{l}\text { Aureobasidium pullulans Ap24 } \\
\text { KX444670 }\end{array}$ & $\begin{array}{l}\text { Aureobasidium pullulans } \\
\text { Ap24 KX444670 }\end{array}$ & No treatment \\
\hline Biol 3 & $\begin{array}{c}\text { Debaryomyces hansenii Dh53 } \\
\text { KX444669 }\end{array}$ & $\begin{array}{c}\text { Debaryomyces hansenii Dh53 } \\
\text { KX444669 }\end{array}$ & $\begin{array}{c}\text { Debaryomyces hansenii Dh53 } \\
\text { KX444669 }\end{array}$ & No treatment \\
\hline
\end{tabular}

${ }^{1}$-Capallo 337.5 SE (fenpropimorph - 19.49\%, metrafenone - 7.31\%, epoxyconazole - 6.09\%, BASF SE, Germany), ${ }^{2}-$ Fandango 200 EC (prothioconazole 10.0\%, fluoxastrobin - 10.0\%, BASF SE, Germany), ${ }^{3}$ - Tarcza Łan $250 \mathrm{EW}$ (tebuconazole $-250 \mathrm{~g} / \mathrm{dm}^{3}$, Sharda Polska Sp. z o.o., Poland), ${ }^{4}$ - Vaxiplant SL (laminarin - 5.0\%, Laboratoires GOËMAR SAS ${ }^{1}$, France), 5 - Duett Star 334 SE (fenpropimorph - 24.56\%, epoxiconazole - 8.25\%, BASF SE, Germany), ${ }^{6}$ - Bumper 250 SC (propiconazole - $25.1 \%$, Makhteshim Chemical Works Ltd, Israel), 7-Gwarant 500 SC (chlorothalonile - 40.16\%, France), 8 - Opera Max 147,5 SE (epoxiconazole - $6.01 \%$, piraclostrobin - $8.18 \%$, Germany).

\section{Inoculation of Wheat Spikes with Fusarium culmorum}

All and entire field-plot experiments were conducted in duplicate. Flowering spikes were inoculated with an aqueous suspension of F. culmorum $\mathrm{Fc} 32$ spores in stage $\mathrm{BBCH}$ 65. The concentration of fungal cells in the suspension was $10^{4}$ cells in $1 \mathrm{~cm}^{3}$ of water. Fungal spores were rinsed off with $5 \mathrm{~cm}^{3}$ of sterile water from fungal colonies cultured for 14 days on PDA (Merck, Poland) at $28^{\circ} \mathrm{C}$. Spikes were inoculated at full flowering (BBCH 65) with a backpack sprayer (Marolex Titan 12, Marolex, Poland).

\section{Evaluation of Wheat Spike Health and Grain Yield}

The severity of FHB symptoms was evaluated in the hard dough stage (BBCH 87) in 100 wheat plants randomly selected from each treatment based on the scale proposed by the European and Mediterranean Plant Protection Organization [45]. The results were expressed as the average percentage of spike surface area affected by the disease. In weakly infected spikes, a single spikelet exhibited FHB symptoms, whereas in severely infected spikes, FBH symptoms were observed on several spikelets. Grain was harvested with a plot harvester in the fully ripe stage (BBCH 92). Grain yield was expressed in grams per $1 \mathrm{~m}^{2}$ of plot area.

\section{Grain Colonization By Yeasts and Fungi of the Genus Fusarium}

The abundance of epiphytic fungi of the genus Fusarium and yeasts colonizing wheat kernels was determined immediately after harvest according Wachowska et al. [37]. Additionally non-disinfected (to obtain epiphytic colonies) and surface-disinfected (to obtain endophytic colonies) kernels were placed on PDA (Merch, Poland) in Petri plates [37]. Colonies of Fusarium spp. were identified [46] after 7 days of incubation at $24^{\circ} \mathrm{C}$ (En 120 incubator, Poland).

The counts of yeasts and Fusarium fungi (N) rinsed off from $1 \mathrm{~g}$ of grain were converted according to the following formula: $\mathrm{N}=\mathrm{n} / 10^{-\mathrm{r}} \cdot \mathrm{v}$, where $\mathrm{v}$ is the number of colonies on the plate, $10^{-\mathrm{r}}$ is the dilution coefficient, and $\mathrm{v}$ is the volume of the plated suspension. 
The colony counts of Fusarium growing on wheat kernels were expressed as a percentage of total kernels within epiphytes and endophytes.

\section{Chemical Analysis of Ergosterol}

Ergosterol was determined by high-performance liquid chromatography (HPLC). Samples containing $100 \mathrm{mg}$ of ground grain were placed in $17 \mathrm{ml}$ culture tubes, suspended in $2 \mathrm{ml}$ of methanol, treated with $0.5 \mathrm{ml}$ of $2 \mathrm{M}$ aqueous sodium hydroxide, and tightly sealed. The tubes were placed inside $250 \mathrm{ml}$ plastic bottles, tightly sealed and microwaved (AVM 401/1WH microwave oven, Whirlpool, Sweden) at $2450 \mathrm{MHz}$ with $900 \mathrm{~W}$ maximum output. Grain samples were irradiated $(370 \mathrm{~W})$ for $20 \mathrm{~s}$ and, approximately $5 \mathrm{~min}$ later, for another $20 \mathrm{~s}$. After 15 minutes, the contents of culture tubes were neutralized with $1 \mathrm{M}$ aqueous hydrochloric acid, $2 \mathrm{ml}$ of $\mathrm{MeOH}$ was added, and the contents were extracted with pentane $(3 \mathrm{x} 4 \mathrm{ml})$. Pentane extracts were pooled and evaporated to dryness in a nitrogen stream. Before analysis, the samples were dissolved in $4 \mathrm{ml}$ of $\mathrm{MeOH}$, filtered through $13 \mathrm{~mm}$ syringe filters with $0.5 \mu \mathrm{m}$ pore diameter (Fluoropore Membrane Filters, Millipore, Ireland), and evaporated to dryness in a nitrogen stream. The sample extract was dissolved in $1 \mathrm{ml}$ of $\mathrm{MeOH}$, and it was analyzed in the Acquity H class UPLC system equipped with a Waters Acquity PDA detector (Waters, USA). Chromatographic separation was performed on the Acquity UPLC $®$ BEH C18 column $(100 \mathrm{~mm} \times 2.1 \mathrm{~mm}$, particle size $1.7 \mu \mathrm{m})$ (Waters, Ireland). Ergosterol was detected with a Waters Acquity PDA detector (Waters, USA) at $282 \mathrm{~nm}$. The presence of ERG was confirmed by comparing retention times and co-injecting every tenth sample with an ergosterol standard.

\section{Trichothecene Analysis}

Sub-samples (10 g) were extracted with acetonitrile/ water (82:18) and purified on a charcoal column (Celite 545/charcoal Draco G/60/activated alumina neutral 4:3:4; w/w/w). Group A trichothecenes (H-2 toxin, T-2 toxin, T-2 tetraol) were analyzed as TFAA derivatives (Table 1). The dried sample was combined with $100 \mu$ of trifluoroacetic acid anhydride. After 20 minutes, the reagent was evaporated to dryness under nitrogen. The residue was dissolved in $500 \mu \mathrm{l}$ of isooctane, and $1 \mu \mathrm{l}$ was injected onto a gas chromatograph-mass spectrometer. Group B trichothecenes (DON, NIV, 3-AcDON, 15-AcDON) were analyzed as trimethylsilyl ether (TMS) derivatives. The dried extract was combined with $100 \mu$ l of the trimethylsilyl imidazole/trimethylchlorosilane (TMSI/TMCS; 100/1 v/v) mixture. After 10 minutes, $500 \mu \mathrm{l}$ of isooctane were added, and the reaction was quenched with $1 \mathrm{ml}$ of water. The isooctane layer was used for analysis, and $1 \mu \mathrm{l}$ of the sample was injected onto the GC/MS system. The analyses were run on a gas chromatograph (Hewlett Packard GC 6890) connected to a mass spectrometer (Hewlett Packard 5972 A, Waldbronn, Germany) with an HP-5MS $0.25 \mathrm{~mm}$ × $30 \mathrm{~m}$ capillary column. Injection port temperature was $280^{\circ} \mathrm{C}$ and transfer line temperature was $280^{\circ} \mathrm{C}$. The analyses were conducted at programmed temperatures, separately for group $\mathrm{A}$ and group $\mathrm{B}$ trichothecenes. The temperature program for group A trichothecenes was as follows: initial temperature of $80^{\circ} \mathrm{C}$ for $1 \mathrm{~min}$, followed by a temperature increase of $80^{\circ} \mathrm{C}-280^{\circ} \mathrm{C}$ at $10^{\circ} \mathrm{C} / \mathrm{min}$, with the final temperature maintained for $4 \mathrm{~min}$. The temperature program for group $\mathrm{B}$ trichothecenes was as follows: initial temperature of $80^{\circ} \mathrm{C}$ for $1 \mathrm{~min}$, followed by a temperature increase of $80^{\circ} \mathrm{C}-200^{\circ} \mathrm{C}$ at $15^{\circ} \mathrm{C} / \mathrm{min}$ for 6 minutes and $200-280^{\circ} \mathrm{C}$ at $10^{\circ} \mathrm{C} / \mathrm{min}$, with the final temperature maintained for $3 \mathrm{~min}$. The helium flow rate was held constant at $0.7 \mathrm{ml} / \mathrm{min}$. A quantitative analysis was performed in the single ion monitored mode (SIM) with the following detection ions: STO -456 and 555; T-2 tetraol - 455 and 568; T-2 triol - 455, 569 and 374; HT-2 - 455 and 327; T-2 - 327 and 401; DON - 103 and 512; 3-AcDON - 117 and 482; 15-AcDON - 193 and 482; NIV - 191 and 600. A qualitative analysis was performed in the SCAN mode (100-700 amu). The recovery rates for the analyzed toxins were as follows:

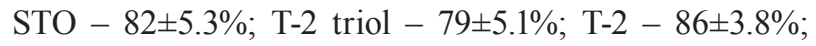
T-2 tetraol - $88 \pm 4.0 \%$; HT-2 - 91 $\pm 3.3 \%$; DON $84 \pm 3.8 \%$; 3 AcDON $-78 \pm 4.8 \% ; 15$ AcDON $-74 \pm 2.2 \%$; and NIV $-81 \pm 3.8 \%$. The limit of detection was $0.01 \mathrm{mg} / \mathrm{kg}$.

\section{Statistical Analysis}

The analysis of variance was performed in the Statistica 12 program. The data regarding the abundance of yeasts and Fusarium spp. communities were log transformed (CFU+1). The significance of differences between means was estimated by analysis of variance and the significance of differences between the average was estimated by the Student-Newman-Keuls (SNK) test $(\mathrm{p}<0.01)$.

\section{Results}

\section{Identification of Yeast Species}

Yeasts isolates belonged to three orders within the divisions Basidiomycota and Ascomycota. $A$. pullulans belonged to Ascomycota, order Dothideales, family Dothideaceae. In the order Saccharomycetales, D. hansenii and C. albicans belonged to the family Debaryomycetaceae, whereas $M$. pulcherrima was a member of the family Metschnikowiaceae. Rhodotorula glutinis belonged to the division Basidiomycota, subdivision Pucciniomycotina, class Microbotryomycetes, order Sporidiobolales, family Sporidiobolaceae. 
Table 4. Grain yield, FHB severity and colonization of winter wheat grain by Fusarium spp. and yeast.

\begin{tabular}{|c|c|c|c|c|c|c|c|c|}
\hline \multirow{3}{*}{$\begin{array}{l}\text { Cultivar/ } \\
\text { inoculation }\end{array}$} & \multirow{3}{*}{ Treatment } & \multirow{3}{*}{ Yield $\mathrm{g} / \mathrm{m}^{2}$} & \multirow{3}{*}{$\begin{array}{c}\text { FHB } \\
\text { severity }\end{array}$} & \multirow{3}{*}{$\begin{array}{c}\text { ERG } \\
(\mathrm{mg} / \mathrm{kg})\end{array}$} & \multicolumn{3}{|c|}{ Fusarium spp. } & \multirow{3}{*}{$\frac{\text { Yeast }}{{\text { CFU x } 10^{2}}^{1 \mathrm{~g}^{-1} \text { grain }^{\mathrm{a}}}}$} \\
\hline & & & & & \multirow{2}{*}{$\frac{C F U \times 10^{2}}{1 \mathrm{~g}^{-1} \text { grain }^{\mathrm{a}}}$} & \multicolumn{2}{|c|}{ Percentage of ${ }^{b}$} & \\
\hline & & & & & & Epiphytes & Endophytes & \\
\hline \multicolumn{9}{|c|}{ Experiment 1 (Bałcyny) } \\
\hline \multirow{4}{*}{ Komnata } & Control & $669.44^{b}$ & 0.55 & 1.27 & $0.35^{\mathrm{a}}$ & $5.56^{\mathrm{abc}}$ & $12.50^{b c}$ & $3.99^{\mathrm{a}}$ \\
\hline & Fung 1 & $638.89^{b}$ & 3.33 & 2.07 & $0.07 \mathrm{de}$ & $13.89 \mathrm{abc}$ & $5.56^{\mathrm{c}}$ & $3.96^{\mathrm{ab}}$ \\
\hline & Integ 1 & $638.61^{b}$ & 1.03 & 6.88 & $0.14^{\mathrm{d}}$ & $4.17^{b c}$ & $2.78^{\mathrm{c}}$ & 3.65 bcd \\
\hline & Biol 1 & $660.83^{b}$ & 2.01 & 9.48 & $0.27 \mathrm{abc}$ & $5.56^{\mathrm{abc}}$ & $2.78^{\mathrm{c}}$ & $4.36^{\mathrm{a}}$ \\
\hline \multirow{4}{*}{$\begin{array}{l}\text { Komnata/ } \\
\text { inoculation with } \\
\text { F. culmorum }\end{array}$} & Control & $608.33^{b}$ & 5.41 & 20.50 & $0.29 \mathrm{abc}$ & $13.89^{a b c}$ & $8.33^{b c}$ & $3.79^{b c}$ \\
\hline & Fung 1 & $646.29^{b}$ & 7.70 & 4.58 & $0^{\mathrm{e}}$ & $12.50^{\mathrm{abc}}$ & $4.17^{b c}$ & 3.69 cde \\
\hline & Integ 1 & $611.11^{\mathrm{b}}$ & 5.43 & 8.66 & $0.26^{\mathrm{c}}$ & $11.11^{\mathrm{abc}}$ & $2.78^{b c}$ & $4.38^{\mathrm{a}}$ \\
\hline & Biol 1 & $644.44^{b}$ & 2.38 & 11.42 & $0.27 \mathrm{abc}$ & $12.50^{\mathrm{abc}}$ & $5.56^{\mathrm{bc}}$ & $4.42^{\mathrm{a}}$ \\
\hline \multirow{4}{*}{ Skagen } & Control & $1118.89^{\mathrm{a}}$ & 0.01 & 0.95 & $0.28 \mathrm{abc}$ & $4.17^{b c}$ & $4.17^{b c}$ & $3.72^{\text {cde }}$ \\
\hline & Fung 1 & $1057.33^{\mathrm{a}}$ & 0.01 & 1.12 & $0.27^{\mathrm{c}}$ & $1.39^{\mathrm{c}}$ & $4.17^{b c}$ & $2.93^{f}$ \\
\hline & Integ 1 & $1123.89^{a}$ & 0.01 & 2.63 & $0.25^{\mathrm{c}}$ & $8.33 \mathrm{abc}$ & $5.56^{\mathrm{c}}$ & $3.26 \mathrm{def}$ \\
\hline & Biol 1 & $1114.17^{\mathrm{a}}$ & 0.04 & 4.27 & $0.14^{d}$ & 6.94 abc & $9.72^{b c}$ & $3.38^{\text {cde }}$ \\
\hline \multirow{4}{*}{$\begin{array}{l}\text { Skagen/ inocu- } \\
\text { lation with } F \text {. } \\
\text { culmorum }\end{array}$} & Control & $1106.67^{\mathrm{a}}$ & 0.75 & 9.35 & $0.29 \mathrm{abc}$ & $20.83^{\mathrm{a}}$ & $9.72^{b c}$ & $2.46^{\mathrm{g}}$ \\
\hline & Fung 1 & $1180.56^{\mathrm{a}}$ & 1.73 & 3.44 & $0.30 \mathrm{abc}$ & $15.28^{a b c}$ & $9.72^{b c}$ & $3.05^{e f}$ \\
\hline & Integ 1 & $1068.33^{a}$ & 0.82 & 2.95 & $0.27^{\mathrm{c}}$ & 19.44 ab & 19.44 ab & $3.90^{\mathrm{b}}$ \\
\hline & Biol 1 & $1135.28^{\mathrm{a}}$ & 0.95 & 5.48 & $0^{\mathrm{e}}$ & $8.33 \mathrm{abc}$ & $23.61^{\text {a }}$ & $0^{\mathrm{h}}$ \\
\hline \multicolumn{9}{|c|}{ Experiment 2 (Bałdy) } \\
\hline \multirow{4}{*}{ Bogatka } & Control & 479.67 ab & 0.08 & 2.06 & $0.31^{\mathrm{a}}$ & $15.28^{\mathrm{a}}$ & 12.50 & $3.55^{\mathrm{a}}$ \\
\hline & Integ 2 & 547.67 ab & 0 & 10.55 & $0.27^{\mathrm{ab}}$ & $11.11^{a b}$ & 8.33 & $2.72 \mathrm{ab}$ \\
\hline & Fung 2 & $537.00^{a b}$ & 0.25 & 3.27 & $0.28^{a b}$ & $9.72^{a b}$ & 15.28 & $2.67 \mathrm{ab}$ \\
\hline & Fung 3 & $580.33^{\mathrm{a}}$ & 0.42 & 3.81 & $0.28^{a b}$ & $2.78^{a b}$ & 12.50 & $3.03^{\mathrm{ab}}$ \\
\hline \multirow{4}{*}{$\begin{array}{l}\text { Bogatka/ inocu- } \\
\text { lation with } F \text {. } \\
\text { culmorum }\end{array}$} & Control & 384.33 ab & 1.00 & 19.41 & $0.16^{\mathrm{b}}$ & $15.29^{\mathrm{a}}$ & 12.50 & $3.09^{\mathrm{ab}}$ \\
\hline & Integ 2 & $315.67^{b}$ & 0 & 5.98 & $0.25^{\mathrm{ab}}$ & $11.11^{\mathrm{ab}}$ & 15.28 & $2.93^{\mathrm{ab}}$ \\
\hline & Fung 2 & $338.00^{a b}$ & 0 & 2.68 & $0.27^{\mathrm{ab}}$ & $4.17^{\mathrm{ab}}$ & 11.11 & $3.41^{\mathrm{a}}$ \\
\hline & Fung 3 & $364.33^{\mathrm{ab}}$ & 0 & 3.49 & $0.28^{\mathrm{ab}}$ & $9.72^{a b}$ & 6.94 & $3.16^{\mathrm{ab}}$ \\
\hline \multicolumn{9}{|c|}{ Experiment 3 (Bałdy) } \\
\hline \multirow{3}{*}{ Tonacja } & Control & 303.30 & 1.36 & 1.11 & $0.29^{\mathrm{a}}$ & $1.39^{\mathrm{b}}$ & 8.33 & $3.78^{a b}$ \\
\hline & Biol 2 & 296.13 & 0.70 & 5.29 & $0.07^{\mathrm{b}}$ & $2.78^{a b}$ & 8.33 & $3.13^{\mathrm{ab}}$ \\
\hline & Biol 3 & 299.97 & 0.33 & 8.49 & $0.30^{\mathrm{a}}$ & $2.77^{\mathrm{ab}}$ & 12.50 & $3.43^{\mathrm{ab}}$ \\
\hline \multirow{3}{*}{$\begin{array}{l}\text { Tonacja/ } \\
\text { inoculation with } \\
\text { F. culmorum }\end{array}$} & Control & 258.51 & 0.78 & 12.36 & $0.32^{a}$ & $9.72^{a b}$ & 0.10 & $3.42^{a b}$ \\
\hline & Biol 2 & 188.44 & 0 & 8.29 & $0.31^{\mathrm{a}}$ & $12.50^{\mathrm{a}}$ & 20.83 & $4.28^{\mathrm{a}}$ \\
\hline & Biol 3 & 181.32 & 2.89 & 6.22 & $0.29^{\mathrm{a}}$ & $8.33^{a b}$ & 16.67 & $3.79 \mathrm{ab}$ \\
\hline
\end{tabular}

a - epiphytes obtained from kernel surfaces in experiment 1 (Bałcyny): F. culmorum - 28.28\%, F. poae - 35.69\%, F. graminearum $3.36 \%$, F. sporotrichioides - 32.65\%), in experiment 2 (Bałdy): (F. culmorum - 26.26\%, F. poae - 69.19\%, F. graminearum - $1.51 \%$ ) and in experiment 3 (Bałdy): (F. culmorum - 15.68\%, F. poae - 75.98\%, F. graminearum - 4.90\%). Values that did not differ significantly in experiments in the SNK test $(\mathrm{p}<0.001)$ are marked with the same letters in columns. 
Dual Culture Assay to Determine the Antagonistic Effects of Epiphytes and Endophytes Against

\section{Fusarium culmorum in vitro}

A total of 77 yeast isolates, identified by sequencing, were selected for in vitro screening by dual culture with F. culmorum (Table 2). Ten out of the 38 epiphytic isolates obtained from the surface of wheat kernels, including four isolates of $D$. hansenii, two isolates of $A$. pullulans and $M$. pulcherrima each, and one isolate of $R h$. glutinis and C. sake each, induced substantial changes in the shape of pathogenic colonies. Fungal colonies cultured in the presence of the above isolates had the shape of elongated ellipsoids with an ellipticity index of less than 0.70. Eight yeast isolates (six isolates of $A$. pullulans and two isolates of M. pulcherrima), including five isolates from kernel tissues, reduced the area of pathogenic colonies by more than $90 \%$.

\section{Fusarium Head Blight and Wheat Grain Yield}

In experiment 1 the yield of control bread wheat cv. Skagen was 1.7 -fold higher (statistically significant) on average in comparison with durum wheat $\mathrm{cv}$. Komnata (Table 3). Fungicides (Fung 1) increased (non-significant) the grain yield of wheat cv. Komnata by $6.24 \%$ (inoculated with $F$. culmorum) relative to unprotected plants, whereas the biological treatment (Biol 1) increased grain yield by $5.93 \%$. The grain yield of wheat cv. Skagen increased (non-significant) by $6.68 \%$ in response to fungicide protection (Fung 1) and by $2.58 \%$ in response to the biological treatment (Biol 1). The increase in the severity of FHB symptoms did not exceed $8 \%$ and was higher in wheat cv. Komnata than in wheat cv. Skagen. The severity of FHB in wheat cv. Komnata (inoculated with F. culmorum) was non-significant reduced by $56.01 \%$ only by the biological treatment (Biol 1) relative to unprotected plants.

In experiment 2 spike inoculation with $F$. culmorum decreased yield by $19.82 \%$, and none of the applied treatments minimized that drop. In non-inoculated treatments subjected to fungicide or integrated protection, grain yield non-significant increased by $11.95 \%$ (Fung 2), $14.17 \%$ (Integ 2) and 20.98\% (Fung 3) relative to non-inoculated control. The severity of FHB symptoms was non-significant reduced by $100 \%$ relative to inoculated control.

In experiment 3 the yield of control plants inoculated with $F$. culmorum non-significant decreased by $14.77 \%$. None of the analyzed treatments increased yields. The severity of FHB symptoms was nonsignificant reduced by $51.47 \%$ (Biol 2, non-inoculated plants) and $100 \%$ (Biol 2, inoculated plants) relative to control.

\section{Content of ERG and Grain Colonization by Yeast and Fungi of the Genus Fusarium}

Spike inoculation with suspensions of $F$. culmorum spores or yeast cells containing ERG increased ERG concentration in the inoculated grain of all wheat cultivars in control treatments and in noninoculated grain in biological treatments (Tables 4). Fungicide (Fung 1) and integrated (Integ 1) treatments significantly decreased the abundance of pathogenic fungi in the non-inoculated grain of wheat cv. Komnata. Fungal colonies of the genus Fusarium were not isolated from the surface of inoculated kernels protected with Fung 1. In the grain of wheat cv. Skagen, fungal abundance was most effectively reduced by Biol 1 . In experiment 3 the biological treatment involving A. pullulans Ap24 (Biol 2) also significantly decreased the abundance of Fusarium spp. in the grain of wheat cv. Tonacja (Table 4).

Yeasts were at least 10 -fold more abundant than Fusarium fungi on the surface of grain in all wheat cultivars (Table 4). Grain was colonized predominantly by $F$. culmorum and $F$. poae which accounted for $60.63 \%$ of all fungal colonies of the genus Fusarium. $F$. graminearum was most prevalent $(11.94 \%)$ on the disinfected kernels of wheat cv. Tonacja and $F$. sporotrichioides was most abundant on the grain of wheat cvs. Komnata and Skagen.

\section{Trichothecene Content of Grain}

All grain samples were contaminated with DON and NIV. Safe levels of DON were exceeded in the inoculated and non-protected grain of all wheat cultivars (Tables 5), in the non-inoculated and biologically protected grain of wheat cv. Skagen and in the inoculated grain of wheat cv. Bogatka subjected to integrated protection (Integ 2). The content of type A trichothecenes differed across wheat cultivars. T-2 tetraol $\left(0.005-0.256 \mathrm{mg} \mathrm{kg}^{-1}\right)$ was detected in most grain samples of wheat cvs. Komnata, Skagen and Bogatka, and its content was highest in the non-inoculated control grain of wheat cv. Komnata. Scirpentriol was detected in most grain samples of wheat cvs. Bogatka and Tonacja at $0.007-0.039 \mathrm{mg} \mathrm{kg}^{-1}$.

The content of DON was determined at $0.473 \mathrm{mg} \mathrm{kg}^{-1}$ in the unprotected grain of durum wheat cv. Komnata, and it increased to $11.704 \mathrm{mg} \mathrm{kg}^{-1}$ after inoculation with $F$. culmorum. In experiment 1, all protective treatments decreased DON concentration in grain inoculated with $F$. culmorum (Table 5). The greatest reduction was noted in the grain of wheat cv. Komnata (Fung 1, 11.41-fold decrease relative to control) where the DON content of control grain exceeded safe levels 6.7 -fold. In the non-inoculated and protected grain of both wheat cultivars, the content of T-2 tetraol 
Table 5. Content of other Fusarium metabolites in winter grain ( $\mathrm{mg} / \mathrm{kg}$ sample).

\begin{tabular}{|c|c|c|c|c|c|c|c|c|c|c|c|c|}
\hline $\begin{array}{l}\text { Cultivar/ } \\
\text { inoculation }\end{array}$ & $\begin{array}{l}\text { Treat- } \\
\text { ment }\end{array}$ & DON & $\begin{array}{l}3 \text { Ac- } \\
\text { DON }\end{array}$ & $\begin{array}{l}15 \mathrm{Ac}- \\
\text { DON }\end{array}$ & FUS-X & NIV & $\begin{array}{l}\text { Sum } \\
\text { TOX }\end{array}$ & STO & $\begin{array}{c}\mathrm{T}-2 \\
\text { Tetraol }\end{array}$ & DAS & HT-2 & $\begin{array}{l}\text { Sum } \\
\text { TOX }\end{array}$ \\
\hline \multicolumn{13}{|c|}{ Experiment 1(Bałcyny) } \\
\hline \multirow{4}{*}{ Komnata } & Control & 0.473 & 0.061 & 0.036 & 0.031 & 0.024 & 0.626 & $<\mathrm{LOD}$ & 0.256 & $<\mathrm{LOD}$ & $<\mathrm{LOD}$ & 0.256 \\
\hline & Fung 1 & 0.294 & 0.040 & 0.020 & 0.031 & 0.043 & 0.429 & $<\mathrm{LOD}$ & 0.005 & $<\mathrm{LOD}$ & $<\mathrm{LOD}$ & 0.005 \\
\hline & Integ 1 & 0.666 & 0.001 & 0.032 & 0.032 & 0.057 & 0.789 & $<\mathrm{LOD}$ & 0.009 & $<\mathrm{LOD}$ & $<\mathrm{LOD}$ & 0.009 \\
\hline & Biol 1 & 0.346 & 0.054 & 0.026 & $<$ LOD & 0.735 & 1.161 & 0.003 & 0.008 & $<\mathrm{LOD}$ & $<$ LOD & 0.011 \\
\hline \multirow{4}{*}{$\begin{array}{l}\text { Komnata/ in- } \\
\text { oculation with } \\
\text { F. culmorum }\end{array}$} & Control & 11.704 & 0.185 & 0.029 & 0.027 & 0.073 & 12.018 & $<\mathrm{LOD}$ & 0.005 & $<\mathrm{LOD}$ & $<\mathrm{LOD}$ & 0.005 \\
\hline & Fung 1 & 1.026 & 0.072 & 0.034 & 0.025 & 0.115 & 1.273 & $<$ LOD & 0.012 & $<\mathrm{LOD}$ & $<\mathrm{LOD}$ & 0.012 \\
\hline & Integ 1 & 1.166 & 0.049 & 0.010 & $<\mathrm{LOD}$ & 0.035 & 1.260 & $<\mathrm{LOD}$ & 0.009 & $<\mathrm{LOD}$ & $<\mathrm{LOD}$ & 0.010 \\
\hline & Biol 1 & 1.119 & 0.072 & 0.022 & $<\mathrm{LOD}$ & 0.114 & 1.327 & $<\mathrm{LOD}$ & 0.015 & $<\mathrm{LOD}$ & $<\mathrm{LOD}$ & 0.015 \\
\hline \multirow{4}{*}{ Skagen } & Control & 0.315 & 0.046 & 0.024 & $<$ LOD & 0.231 & 0.616 & $<\mathrm{LOD}$ & 0.019 & $<\mathrm{LOD}$ & $<\mathrm{LOD}$ & 0.020 \\
\hline & Fung 1 & 0.039 & $<\mathrm{LOD}$ & 0.009 & $<$ LOD & 0.029 & 0.078 & 0.006 & $<\mathrm{LOD}$ & $<\mathrm{LOD}$ & $<\mathrm{LOD}$ & 0.006 \\
\hline & Integ 1 & 0.04 & 0.001 & 0.009 & $<$ LOD & 0.032 & 0.082 & $<\mathrm{LOD}$ & 0.013 & $<\mathrm{LOD}$ & $<\mathrm{LOD}$ & 0.013 \\
\hline & Biol 1 & 1.647 & 0.018 & 0.008 & $<\mathrm{LOD}$ & 0.008 & 1.681 & 0.004 & 0.005 & $<\mathrm{LOD}$ & $<\mathrm{LOD}$ & 0.009 \\
\hline \multirow{4}{*}{$\begin{array}{c}\text { Skagen/ in- } \\
\text { oculation with } \\
\text { F. culmorum }\end{array}$} & Control & 7.383 & 0.116 & 0.017 & 0.036 & 0.072 & 7.623 & 0.004 & 0.014 & $<\mathrm{LOD}$ & $<\mathrm{LOD}$ & 0.018 \\
\hline & Fung 1 & 0.105 & 0.140 & 0.015 & $<\mathrm{LOD}$ & 0.051 & 0.311 & $<\mathrm{LOD}$ & 0.005 & $<\mathrm{LOD}$ & $<\mathrm{LOD}$ & 0.005 \\
\hline & Integ 1 & 0.322 & 0.061 & 0.034 & 0.026 & 0.122 & 0.566 & $<\mathrm{LOD}$ & 0.012 & $<\mathrm{LOD}$ & $<\mathrm{LOD}$ & 0.012 \\
\hline & Biol 1 & 1.776 & 0.041 & 0.025 & 0.025 & 0.027 & 1.895 & $<\mathrm{LOD}$ & 0.043 & $<\mathrm{LOD}$ & $<\mathrm{LOD}$ & 0.043 \\
\hline \multicolumn{13}{|c|}{ Experiment 2 (Bałdy) } \\
\hline \multirow{4}{*}{ Bogatka } & Control & 0.106 & 0.003 & 0.001 & 0.001 & 0.025 & 0.136 & $<\mathrm{LOD}$ & 0.006 & $<\mathrm{LOD}$ & $<\mathrm{LOD}$ & 0.006 \\
\hline & Integ 2 & 0.053 & 0.001 & 0.001 & 0.001 & 0.028 & 0.084 & 0.007 & 0.005 & $<\mathrm{LOD}$ & $<\mathrm{LOD}$ & 0.012 \\
\hline & Fung 2 & 0.133 & 0.014 & 0.006 & 0.023 & 0.041 & 0.217 & 0.012 & 0.005 & $<\mathrm{LOD}$ & $<\mathrm{LOD}$ & 0.017 \\
\hline & Fung 3 & 0.145 & 0.029 & 0.065 & 0.188 & 0.127 & 0.554 & 0.006 & 0.016 & $<\mathrm{LOD}$ & 0.004 & 0.026 \\
\hline \multirow{4}{*}{$\begin{array}{c}\text { Bogatka/ } \\
\text { inoculation } \\
\text { with } \\
\text { F. culmorum }\end{array}$} & Control & 6.128 & 0.314 & 0.042 & 0.026 & 0.064 & 6.575 & 0.017 & 0.006 & $<\mathrm{LOD}$ & $<\mathrm{LOD}$ & 0.023 \\
\hline & Integ 2 & 1.759 & 0.026 & 0.009 & 0.125 & 0.191 & 2.109 & 0.010 & 0.006 & $<\mathrm{LOD}$ & $<$ LOD & 0.016 \\
\hline & Fung 2 & 0.659 & 0.015 & 0.005 & 0.069 & 0.098 & 0.846 & 0.008 & 0.020 & $<$ LOD & 0.003 & 0.031 \\
\hline & Fung 3 & 0.878 & 0.019 & 0.008 & 0.088 & 0.090 & 1.084 & 0.025 & 0.004 & $<\mathrm{LOD}$ & 0.002 & 0.031 \\
\hline \multicolumn{13}{|c|}{ Experiment 3 (Bałdy) } \\
\hline \multirow{3}{*}{ Tonacja } & Control & 1.099 & 0.044 & 0.013 & 0.012 & 0.453 & 1.621 & 0.007 & 0.009 & $<\mathrm{LOD}$ & 0.004 & 0.020 \\
\hline & Biol 2 & 0.939 & 0.032 & 0.011 & 0.012 & 0.236 & 1.228 & 0.006 & $<$ LOD & 0.001 & 0.011 & 0.018 \\
\hline & Biol 3 & 0.567 & 0.019 & 0.006 & 0.009 & 0.025 & 0.626 & 0.003 & $<\mathrm{LOD}$ & $<\mathrm{LOD}$ & $<\mathrm{LOD}$ & 0.003 \\
\hline \multirow{3}{*}{$\begin{array}{c}\text { Tonacja/ } \\
\text { inoculation } \\
\text { with } \\
\text { F. culmorum }\end{array}$} & Control & 7.808 & 0.143 & 0.048 & 0.027 & 0.167 & 8.193 & 0.010 & $<\mathrm{LOD}$ & $<\mathrm{LOD}$ & $<\mathrm{LOD}$ & 0.010 \\
\hline & Biol 2 & 0.849 & 0.035 & 0.005 & 0.005 & 0.071 & 0.965 & $<\mathrm{LOD}$ & $<\mathrm{LOD}$ & $<\mathrm{LOD}$ & $<\mathrm{LOD}$ & $<\mathrm{LOD}$ \\
\hline & Biol 3 & 0.689 & 0.024 & 0.007 & 0.012 & 0.023 & 0.757 & 0.039 & $<\mathrm{LOD}$ & 0.002 & $<\mathrm{LOD}$ & 0.041 \\
\hline
\end{tabular}

LOD - limit of detection, LOD for all mycotoxins is $0.001(\mathrm{mg} / \mathrm{kg})$

was lower than in unprotected grain. In experiment location 2, the concentration of DON in the inoculated and protected grain of wheat cv. Bogatka was at least 3 -fold lower than in control grain. In non-inoculated grain, DON levels were reduced only by integrated protection. In experiment 3 all biological treatments decreased the content of DON and NIV both with and without inoculation with F. culmorum (Table 5). Isolate D. hansenii Dh53 (Biol 3) was most effective, and it reduced DON concentration in inoculated grain 
11.33-fold and NIV concentration in non-inoculated grain by 18.12 -fold relative to control.

\section{Discussion}

The results of this study indicate that yeasts obtained from winter wheat grain are promising biological control agents (BCAs) that inhibit the development of F. culmorum and decrease trichothecene concentrations in the grain of bread wheat and durum wheat. In this study, three foliar BCA treatments applied to wheat plants inoculated with $F$. culmorum decreased the DON content of grain below $1.250 \mathrm{mg} \mathrm{kg}^{-1}$ in most cases. Skagen was the only wheat cultivar where the concentration of DON remained high after biological treatment at $1.647 \mathrm{mg} \mathrm{kg}^{-1}$ in non-inoculated grain and $1.776 \mathrm{mg} \mathrm{kg}^{-1}$ in inoculated grain. Similar results were reported by Matarese et al. [47], where only one of the ten analyzed isolates of the genus Trichoderma reduced DON concentration in F. culmorum-inoculated grain in vivo, but only to $1.75 \mathrm{mg} \mathrm{kg}^{-1}$. In a field study conducted by Schisler et al. [26], isolate Cryptococcus flavescens OR 182.9 decreased trichothecene concentrations to up to $2.8 \mathrm{ppm}$ in naturally infected grain. In a greenhouse experiment evaluating seven FHB antagonists, only Bacillus strains 43.3 and 43.4 and the Cryptococcus OH182.9 strain reduced disease severity by $48-95 \%$ and decreased DON concentration in grain by $83-$ $98 \%$ [25]. However, the same antagonistic strains delivered variable results under field conditions. Bacillus strains had no effect on either FHB severity or DON concentration in grain, whereas strain $\mathrm{OH}$ 182.9 reduced FHB severity and DON content by $50 \%$ [25, 27]. According to Khan and Doohan [48], Pseudomonas flourescens strains induced a significant $74 \%$ decrease in DON levels. Kim and Vujanovic [49] found that fungal isolate Sphaerodes mycoparasitica SMCD 2220-01 was a host-specific mycoparasitic against plant-pathogenic Fusarium species. The tested isolate also reduced DON content by $89 \%$. The above authors also demonstrated that $S$. mycoparasitica SMCD 2220-01 was capable of transforming DON to the less toxic deoxynivalenol sulfate [49].

In our study, $19 \%$ of $D$. hansenii, Rh. glutinis, $A$. pullulans, M. pulcherrimia and $C$. sake isolates grown in dual culture with $F$. culmorum significantly inhibited the pathogen's growth. A screening study conducted by Comby et al. [50] revealed that isolates of yeast species $R h$. kratochvilovae, Rh. lysiniphila and Sporobolomyces roseus inhibited the development of $F$. culmorum and $F$. graminearum colonies by $3-14.5 \%$. In the above study, Aureobasidium protae reduced the development of pathogenic colonies by $25-37.5 \%$. The potential ability of $A$. pullulans to inhibit the growth of $F$. culmorum on wheat grain was also reported by Wachowska et al. [37]. A. pullulans is used in commercial preparations for post-harvest control of pathogens (BoniProtect) and fireblight (BlossomProtect) [34, 51].
There is extensive evidence to indicate that A. pullulans isolates produce aureobasidin, a compound with fungicidal properties [52], or fusigen, a siderophore which chelates iron and enables the antagonist to compete more effectively for iron with the pathogen [53]. Castoria et al. [54] studied the effectiveness of $A$. pullulans against the $B$. cinerea pathogen in stored apples and observed high levels of activity of $\beta$-1,3-glucanase, an enzyme produced by this antagonist. In the work of Ippolito et al. [55], A. pullulans produced extracellular enzymes exochitinase and $\beta$-1,3-glucanase in wounded apples and in vitro. These enzymes degrade the walls of pathogenic cells and induce resistance in plants [55]. In the current study, A. pullulans most probably exerted protective effects by competing with Fusarium fungi for space and nutrients. This hypothesis is supported by the following observations: (1) A. pullulans was most effective in decreasing the area of fungal colonies in dual cultures; (2) the discussed yeast was most abundant on the grain of bread wheat inoculated with F. culmorum; (3) A. pullulans effectively minimized the symptoms of FHB; (4) the analyzed yeast decreased grain colonization by fungi of the genus Fusarium; (5) A. pullulans was less effective than other yeasts only in its ability to reduce DON levels in grain (by $14.64 \%$ in non-inoculated grain). In a field study by Schisler et al. [26], yeast isolate Cryptococcus flavescens $\mathrm{OH} 71.4$ was not highly effective in reducing DON concentration (up to $20 \%$ ) in the grain of two bread wheat cultivars.

In the present study, the following observations suggest that the isolate of $D$. hansenii (applied three times) produced biocidal compounds: (1) the shape of $F$. culmorum colonies grown with $D$. hansenii in dual cultures changed significantly; (2) D. hansenii was not highly effective in reducing the severity of FHB symptoms or decreasing grain colonization by Fusarium fungi; (3) D. hansenii significantly decreased DON concentration in grain. Debaryomyces hansenii (anamorph of Candida famata) is generally a nonpathogenic species which is resistant to salinity and low temperature. The species easily adapts to various ecosystems, and it is used in the biological protection of crops against Penicillium spp. [56] and Botrytis cinerea [57]. Debaryomyces hansenii also exerts antagonistic effects on pathogens colonizing foods, such as dairy products [58], dry-cured meat products [59] and dry-fermented sausage [60]. Interestingly, $D$. hansenii isolated from cheeses also exerted fungicidal effects on Candida albicans and C. neoformans which are dangerous for humans [61, 62]. The most widely described biocidal mechanism of $D$. hansenii against fungi relies on killer toxins [63] with a molecular mass of 22-23 kDA [64, 65, 66]. According to Żarowska [63], D. hansenii killer toxins probably bind to $\beta$-(1,6)-glucan in the cell walls of sensitive fungi and to an unidentified receptor in the cytoplasmic membrane, and they eliminate fungal cells by inhibiting their division. The European Food Safety Authority [66] has 
qualified $D$. hansenii has as an isolate with qualified presumption of safety (QPS) status for industrial and commercial applications [67].

Three biological treatments involving the cell suspensions of yeast species C. sake, Rh. glutinis and $D$. hansenii were least effective against FHB in wheat. In the biologically protected grain of wheat cv. Skagen, DON concentration was determined at $1.647 \mathrm{mg} \mathrm{kg}^{-1}$, and it exceeded the safe limit of $1250 \mu \mathrm{g} \mathrm{kg}^{-1}$. The isolate of $R h$. glutinis was characterized by a low growth rate and moderate activity in vitro. Lima et al. [68] found that Rh. glutinis exerted antagonistic effects on pathogens only at low temperatures. In the present study, $C$. sake effectively inhibited the development of F. culmorum in vitro, but it was not a reliable antagonist under field conditions. Laitila et al. [34] also demonstrated that C. sake exerted inhibitory effects against $F$. cerealia and $F$. equiseti. Candida sake is an ingredient of Candifruit, a commercial product for post-harvest control of pathogens. However, Candifruit is registered as a plant strengthening agent in Spain [51].

In this study, DON concentration was at least 1.5 -fold higher in durum wheat grain inoculated with F. culmorum than in bread wheat grain. In a study conducted in southern Poland, Gorczyca et al. [7] demonstrated that wheat cv. Komnata had a high propensity for accumulating DON. The concentration of DON was 3.5-fold higher in the grain of wheat cv. Komnata than in the Austrian cultivar Auradur. In the work of Langevin et al. [69], durum wheat spikes were rapidly colonized by both trichothecene-producing and non-producing $F$. graminearum strains. The above authors suggested that durum wheat harboring genomes $\mathrm{A}$ and $\mathrm{B}$ does not have type II resistance against fungal pathogens. Bread wheat also harbors genomes A and $\mathrm{B}$, but in a field study conducted by Langevin et al. [69], this species was significantly less infected by $F$. graminearum strains non-producing trichothecenes. For this reason, the cited authors probably concluded that genome $\mathrm{D}$ is more likely to harbor genes that encode type II resistance.

It should also be noted that the effectiveness of BCAs is largely determined by the severity of FHB, cultivar, environmental conditions and the mycotoxin content of grain. In our study, DON (40-1647 $\mu \mathrm{g} \mathrm{kg}^{-1}$ grain) and NIV (23-735 $\mu \mathrm{g} \mathrm{kg}^{-1}$ grain) were detected in all samples of non-inoculated grain harvested in 2017. The concentrations of these mycotoxins were generally higher than those reported by Bryła et al. [8]. In northeastern Poland, bread wheat and durum wheat were colonized mainly by $F$. culmorum and rarely by $F$. poae. In contrast, $F$. avenaceum [7] and $F$. graminearum [5] were the predominant pathogens of durum wheat in southern Poland. Fusarium graminearum is the predominant pathogen of wheat in Europe, including in Hungary, Serbia-Montenegro and Austria [70, 71], Finland and Russia (European part) [72], Germany [73] and France [74].

\section{Conclusions}

The results of this study indicate that yeasts colonizing wheat grain can be applied as biological treatments to reduce the severity of FHB and decrease trichothecene concentrations in grain during heading, flowering and ripening. Yeast isolates should be thoroughly identified and tested before application. Yeasts have a complex mechanism of action and are sensitive to environmental factors; therefore, further research is required to select yeast isolates characterized by high levels of activity, high survivability on the protected plants, and low sensitivity to adverse environmental conditions in the field. Yeast biocontrol mechanisms represent unexplored field of research and plentiful opportunities for the development of commercial, yeast-based applications for plant protection.

\section{Conflict of Interest}

The authors declare no conflict of interest.

\section{References}

1. CSO. Central Statistical Office. Concise Statistical Yearbook of Poland (2017) Available online: https:// danepubliczne.gov.pl/dataset/5c9f136c-025d-4b82b03c-d8d7148dfe09//resource/cd90dfe3-1665-4a4db034-25e 0ead1b389/download/malyrocznikstaty stycznypolski2017.pdf (accessed on 24 February 2020)

2. MA Z., XIE Q., LI G., JIA H., ZHOU J., KONG Z., LI N., YUAN Y. Germplasms, genetics and genomics for better control of disastrous wheat Fusarium head blight. Theor. Appl. Genet. https://doi.org/10.1007/s00122-019-03525-8, 2020.

3. NAZARI L., PATTORI E., SOMMA S., MANSTRETTA V., WAALWIJK C., MORETTI A., MECA G., ROSSI V. Infection incidence, kernel colonisation, and mycotoxin accumulation in durum wheat inoculated with Fusarium sporotrichioides, $F$. langsethiae or $F$. poae at different growth stages. Eur. J. Plant Pathol. 153, 715, 2019.

4. XU X.-M., NICHOLSON P., THOMSETT M.A., SIMPSON D., COOKE B.M., DOOHAN F.M., BRENNAN J., MONAGHAN S., MORETTI A., MULE G., HORNOK L., BEKI E., TATNELL J., RITIENI A., EDWARDS S. G. Relationship between the fungal complex causing fusarium head blight of wheat and environmental conditions. Phytopathol. 98 (1), 69, 2008.

5. WIŚNIEWSKA H., STĘPIEŃ Ł., WAŚKIEWICZ A., BESZTERDA M., GÓRAL T., BELTER J. Toxigenic Fusarium species infecting wheat heads in Poland. Cent. Eur. J. Biol. 9, 163, 2014.

6. BUŚKO M., STUPER K., JELEŃ H., GÓRAL T., CHMIELEWSKI J., TYRAKOWSKA B., PERKOWSKI J. Comparison of volatiles profile and contents of trichothecenes group b, ergosterol, and ATP of bread wheat, durum wheat, and triticale grain naturally contaminated by mycobiota. Front. Plant Sci. 7, 1243, 2016.

7. GORCZYCA A., OLEKSY A., GALA-CZEKAJ D., URBANIAK M., LASKOWSKA M., WAŚKIEWICZ 
A., STĘIEŃ Ł. Fusarium head blight incidence and mycotoxin accumulation in three durum wheat cultivars in relation to sowing date and density. The Science of Nature 105 (1), 2, 2018.

8. BRYŁA M., KSIENIEWICZ-WOŹNIAK E., WAŚKIEWICZ A., SZYMCZYK K., JĘDRZEJCZAK R. Natural occurrence of nivalenol, deoxynivalenol, and deoxynivalenol-3-glucoside in polish winter wheat. Toxins 10, 81, 2018

9. GÓRAL T., WIŚNIEWSKA H., OCHODZKI P., WALENTYN-GÓRAL D. Higher Fusarium toxin accumulation in grain of winter triticale lines inoculated with Fusarium culmorum as compared with wheat. Toxins 8, 301, 2016.

10. MISHRA S., DWIVEDI P.D., PANDEY H.P., DAS M. Role of oxidative stress in deoxynivalenol induced toxicity. Food Chem Toxicol. 72, 20, 2014.

11. MASUDA E., TAKEMOTO T., TATSUNO T., OBARA T. Immunosuppressive effect of a trichothecene mycotoxin, Fusarenon-X in mice. Immunology. 45 (4), 743, 1982.

12. NITAO J.K., MEYER S.L., SCHMIDT W.F., FETTINGER J.C., CHITWOOD D.J. Nematode-antagonistic trichothecenes from Fusarium equiseti. J. Chem. Ecol. 27 (5), 859, 2001.

13. NDOSSI D.G1, FRIZZELL C., TREMOEN N.H., FÆSTE C.K., VERHAEGEN S., DAHL E., ERIKSEN G.S., SØRLIE M., CONNOLLY L., ROPSTAD E. An in vitro investigation of endocrine disrupting effects of trichothecenes deoxynivalenol (DON), T-2 and HT-2 toxins. Toxicol. Lett. 214 (.3), 268, 2012.

14. VENKATARAMANA M., SELVAKUMAR G., CHANDRANAYAKA S. Fusarium Mycotoxin: Toxicity and Detection. In book: Microbial Toxins, 465, 2018.

15. STUPER-SZABLEWSKA K., PERKOWSKI J. Contamination of wheat grain with microscopic fungi and their metabolites in Poland in 2006-2009. Ann. Agric. Environ. Med. 21 (3), 504, 2014.

16. MCCORMICK SP1, STANLEY A.M., STOVER N.A., ALEXANDER N.J. Trichothecenes: from simple to complex mycotoxins. Toxins. 3 (7), 802, 2011.

17. PESTKA J.J., FORSTELL J.H. Inhibition of human lymphocyte transformation by the macrocyclic trichothecenes roridin A and verrucarin A. Toxicol. Lett. 41, 215, 1988.

18. SEONG K.-Y., PASQUALI M., ZHOU X., SONG J., HILBRUN K., MCCORMICK S.P., DONG Y., XU J.R., KISTLER H.C. Global gene regulation by Fusarium transcription factors Tri6 and Tri10 reveals adaptations for toxin biosynthesis. Mol. Microbiol. 72, 354, 2009.

19. UENO Y. Toxicological features of T-2 toxin and related trichothecenes. Fundam. Appl. Toxicol. 4, 124, 1984.

20. BONDY G.S., MCCORMICK S.P., BEREMAND M.N., PESTKA J.J. Murine lymphocyte proliferation impaired by substituted neosolaniols and calonectrins-Fusarium metabolites associated with trichothecene biosynthesis. Toxicon. 29,1107, 1991.

21. ALEXANDER N.J., MCCORMICK S.P., ZIEGENHORN S.L. Phytotoxicity of selected trichothecenes using Chlamydomonas reinhardtii as a model system. Nat. Toxins. 7, 265, 1999.

22. Directive 2009/128/EC of the European Parliament and of the Council of 21 October 2009 establishing a framework for Community action to achieve the sustainable use of pesticides (accessed on 24 February 2018)

23. BAFFONI L., GAGGIA F., DALANAJ N., PRODI A., NIPOTI P., PISI A., BIAVATI B., DI GIOIA D. Microbial inoculants for the biocontrol of Fusarium spp. in durum wheat. BMC Microbiol. 15, 242, 2015.

24. EL-HASAN A., SCHÖNE J., HÖGLINGER B., WALKER F., VOEGELE R.F. Assessment of the antifungal activity of selected biocontrol agents and their secondary metabolites against Fusarium graminearum. Eur. J. Plant Pathol. 150 (1), 91, 2018.

25. SCHISLER D.A., KHAN N.I., BOEHM M.J. Biological control of fusarium head blight of wheat and deoxynivalenol levels in grain via use of microbial antagonists. Adv. Exp. Med. Biol. 504, 53, 2002.

26. SCHISLER D.A., SLININGER P.J., BOEHM M.J., PAUL P.A. Co-culture of yeast antagonists of Fusarium head blight and their effect on disease development in wheat. Papers in Plant Pathol. 385, 10(4), 128, 2011.

27. PIRGOZLIEV S.R., EDWARDS S.G., HARE M.C., JENKINSON P. Strategies for the control of Fusarium head blight in cereals. Eur. J. Plant Pathol. 109, 731, 2003.

28. Commission Recommendation of 27 March 2013 on the Presence T-2 and HT-2 Toxin in Cereals and Cereal Products. Available online: http://eur-lex.europa.eu/legalcontent/EN/ALL/?uri=CELEX:32013H0165 (accessed on 2 December 2017)

29. Commission Regulation EC No $1881 / 2006$ of 19 December 2006 Setting Maximum Levels for Certain Contaminants for Foodstuffs. Available online: http://eurlex.europa.eu/legal-content/EN/TXT?url=CELEX:0200 6R1881-20170728 (accessed on 2 December 2017)

30. LINDBLAD M., GIDLUND A., SULYOK M., BÖRJESSON T., KRSKA R., OLSEN M., FREDLUND E. Deoxynivalenol and other selected Fusarium toxins in Swedish wheat-occurrence and correlation to specific Fusarium species. Int. J. Food Microbiol. 167, 284, 2013.

31. KUCHARSKA K., WACHOWSKA U. The microbiome on the leaves of crop plants. Advances in Microbiol. 53 (4), 352,2014

32. OLSTROPE M., BORLING J., SCHNURER J., PASSOTH V. Pichia anomala yeast improves feed hygiene during storage of moist crimped barley grain under Swedish farm conditions. Anim. Feed Sci. Technol. 156, 37, 2010.

33. HILBER-BODMER M., SCHMID M., AHRENS C.H., FREIMOSER F.M. Competition assays and physiological experiments of soil and phyllosphere yeasts identify Candida subhashii as a novel antagonist of filamentous fungi. BMC Microbiol. 17, 4, 2017.

34. LAITILA A., SARLIN T., RAULIO M., WILHELMSON A., KOTAVIITA E., HUTTUNEN T., JUVONEN R. Yeasts isolated from industrial maltings can suppress Fusarium growth and formation of gushing factors. J. Ind. Microbiol. Biotechnol. 34 (11), 701, 2007.

35. WACHOWSKA U., GŁOWACKA K., MIKOŁAJCZYK W., KUCHARSKA K. Biofilm of Aureobasidium pullulans var. pullulans on winter wheat kernels and its effect on other microorganisms. Microbiol. 85 (5), 523, 2016.

36. CSERHÁTI M., KRISZT B., KRIFATON C., SZOBOSZLAY S., HAHN J., TOTH S., NAGY I., KUKOLYA J. Mycotoxin-degradation profile of Rhodococcus strains. Int. J. Food Microbiol. 166, 176, 2013.

37. WACHOWSKA U., WAŚKIEWICZ A., JĘDRYCZKA M. Reduction of Fusarium pathogens and mycotoxins contaminating winter wheat grain by protective treatment. Pol. J. Environ. Stud. 26 (5), 1, 2017. 
38. MARTIN J. . Use of acid, rose Bengal and streptomycin in the plate method for estimating soil fungi. Soil Science $38,215,1950$

39. KURTZMAN C., FELL J.W., BOEKHOUT T. The yeasts: a taxonomic study. Elsevier, Londyn, 2080, 2011.

40. WHITE T.J., BRUNS T., LEE S., TAYLOR J.W. Amplification and direct sequencing of fungal ribosomal RNA genes for phylogenetics. 315-322. In: PCR Protocols: A Guide to Methods and Applications, eds. Innis, M. A., D. H. Gelfand, J. J. Sninsky, and T. J. White. Academic Press, Inc., New York, 1990.

41. http://blast.ncbi.nlm.nih.gov/Blast.cgi (accessed on 4 July 2015)

42. RASBAND W.S. ImageJ, U. S. National Institutes of Health, Bethesda, MD, USA. http://rsb.info.nih.gov/ij/ (accessed on 02 Dec 2018), 1997-2011.

43. GÓRAL T., WALENTYN-GÓRAL D. Variation for resistance to Fusarium head blight in winter and spring wheat varieties studied in 2009-2016. Short communication. Bulletin Plant Breed. Acclimat. Instit. 284, 3, 2018.

44. GÓRAL T., WIŚNIEWSKA H., WALENTYN-GÓRAL D., RADECKA-JANUSIK M., PAWEE CZEMBOR P. Resistance to Fusarium head blight (Fusarium culmorum (W.G. Sm.) Sacc.) of winter wheat lines generated from crosses between winter type cultivars and resistant spring wheat Sumai 3. Progr. Plant Protect. 56 (3), 285, 2016.

45. EPPO Bulletin. Foliar and ear diseases on cereals. 42 (3), (https://onlinelibrary. wiley.com), 2012. 23:443

46. LESLIE J.F., SUMMERELL B.A. The Fusarium laboratory manual. 1st ed. Blackwell Publishing Ltd; Oxford, London, 388, 2006.

47. MATARESE F., SARROCCO S., GRUBER S., SEIDLSEIBOTH V., VANNACCI G. Biocontrol of Fusarium head blight: interactions between Trichoderma and mycotoxigenic Fusarium. Microbiol. 158, 98, 2012.

48. KHAN M.R., DOOHAN F.M. Bacterium-mediated control of Fusarium head blight disease of wheat and barley and associated mycotoxin contamination of grain. Biol. Contr. 48, 42, 2009.

49. KIM S.H., VUJANOVIC V. Relationship between mycoparasites lifestyles and biocontrol behaviors against Fusarium spp. and mycotoxins production. Appl. Microbiol. Bio. 100 (12), 5257, 2016.

50. COMBY M., GACOIN M., ROBINEAU M., RABENOELINA F., PTAS S., DUPONT J., PROFIZI C., BAILLIEUL F. Screening of wheat endophytes as biological control agents against Fusarium head blight using two different in vitro tests. Microbiol. Res. 202, 11, 2017.

51. SUNDH I., MELIN P. Safety and regulation of yeasts used for biocontrol or biopreservation in the food or feed chain. Antonie van Leeuwenhoek 99, 113, 2011.

52. SLIGHTOM J.L., METZGER B.P., LUU H.T., ELHAMMER A.P. Cloning and molecular characterization of the gene encoding the aureobasidin A bosynthesis complex in Aureobasidium pullulans BP-1938. Gene. 431, 67, 2009.

53. WANG W., CHI Z., LIU G., BUZDAR M.A., CHI Z. Chemical and biological characterization of siderophore produced by the marine-derived Aureobasidium pullulans HN6.2 and its antibacterial activity. Biometals. 22, 965, 2009.

54. CASTORIA R., DE CURTIS F., LIMA G., CAPUTO L., PACIFICO S., DE CICCO V. Aureobasidium pullulans (LS-30) an antagonist of postharvest pathogens of fruits:
Study on its modes of action. Postharvest Biol. Technol. 22 (1), 1, 2001.

55. IPPOLITO A., EL GHAOUTH A., WILSON C.L., WISNIEWSKI M. Control of postharvest decay of apple fruit by Aureobasidium pullulans and induction of defense responses. Postharvest Biol. Technol. 19, 265, 2000.

56. DROBY S., CHALUTZ E., WILSON C.L., WISNIEWSKI M. Characterization of the biocontrol activity of Debaryomyces hansenii in the control of Penicillium digitatum on grapefruit. Can. J. Microbiol. 35 (8), 794, 1989.

57. SANTOS A., SANCHEZ A., MARQUINA D. Yeasts as biological agents to control Botrytis cinerea. Microbiol. Res. 159, 331, 2004.

58. LIU S-Q., TSAO M. Biocontrol of dairy moulds by antagonistic dairy yeast Debaryomyces hansenii in yoghurt and cheese at elevated temperatures. Food Control. 20, 852, 2009.

59. ANDRADE M.J., THORSEN L., RODRÍGUEZ A., CORDOBA J.J., JESPERSEN L., Inhibition of ochratoxigenic moulds by Debaryomyces hansenii strains for biopreservation of dry-cured meat products. Int. J. Food. Microbiol. 170, 70, 2014.

60. NÚNEZ F., LARA M.S., PEROMINGO B., DELGADO J., SANCHEZ-MONTERO L., ANDRADE M.J. Selection and evaluation of Debaryomyces hansenii isolates as potential bioprotective agents against toxigenic penicillia in dry-fermented sausages. Food Microbiol. 46, 114, 2015.

61. AL-QAYSI S.A.S., AL-HAIDERI H., THABIT Z.A. Production, characterization, and antimicrobial activity of mycocin produced by Debaryomyces hansenii DSMZ70238. Int. J. Microbiol. ID 2605382, 9, 2017.

62. BANJARA N., NICKERSON K.W., SUHR M.J., HALLEN-ADAMS H.E. Killer toxin from several foodderived Debaryomyces hansenii strains effective against pathogenic Candida yeasts. Int. J. Food Microbiol. 222, 23, 2016.

63. ŻAROWSKA B. Biosynthesis and characteristics of Debaryomyces hansenii killer toxin. University of Environmental and Life Sciences Publishing House. Monograph. 146, 17, 2012.

64. SANTOS A., MARQUINA D., BARROSO J., PEINADO J.M. (1-6)-b-D-glucan as the cell wall binding site for Debaryomyces hansenii killer toxin. Lett. Appl. Microbiol. 34, 95, 2002.

65. SCHAFFRATH R., MEINHARDT F., KLASSEN R. Yeast killer toxins: fundamentals and applications. In: Anke T., Schüffler A. (eds) Physiology and Genetics. The Mycota (A comprehensive treatise on fungi as experimental systems for basic and applied research), 15 Springer, Cham, 2018.

66. BIOHAZ. https://www.efsa.europa.eu (accessed on 7 May 2018) 2012.

67. GRZEGORCZYK M., ŻAROWSKA B., RESTUCCIA C., CIRVILLERI G. Postharvest biocontrol ability of killer yeasts against Monilinia fructigena and Monilinia fructicola on stone fruit. Food Microbiol. 61, 93, 2017.

68. LIMA G., DE CURTIS F., CASTORIA R., DE CICCO $\mathrm{V}$. Integrated control of apple postharvest pathogens and survival of biocontrol yeasts in semi-commercial conditions. Eur. J. Plant Pathol. 109, 341, 2003.

69. LANGEVIN F., EUDES F., COMEAU A. Effect of trichothecenes produced by Fusarium graminearum during fusarium head blight development in six cereal species. Eur. J. Plant Pathol. 110, 735, 2004.

70. LÁDAY M., JUHÁSZ Á., MULÈ G., MORETTI A., SZÉCSI Á., LOGRIECO A. Mitochondrial DNA diversity 
and lineage determination of European isolates of Fusarium graminearum (Gibberella zeae). Eur. J. Plant Pathol. 110, 545, 2004.

71. TÓTH B., MESTERHÁZY Á., HORVÁTH Z., BARTÓK T., VARGA M., VARGA J. Genetic variability of central European isolates of the Fusarium graminearum species complex. Eur. J. Plant Pathol. 113, 35, 2005.

72. YLI-MATTILA T., GAGKAEVA T., WARD T.J., AOKI T., KISTLER H.C., O'DONNELL K.A. novel Asian clade within the Fusarium graminearum species complex includes a newly discovered cereal head blight pathogen from the Russian Far East. Mycol. 101, 841, 2009.

73. TALAS F., PARZIES H.K., MIEDANER T. Diversity in genetic structure and chemotype composition of Fusarium graminearum sensu stricto populations causing wheat head blight in individual fields in Germany. Eur. J. Plant Pathol. 131, 39, 2011.

74. BOUTIGNY A.L., WARD T.J., BALLOIS N., IANCU G., IOOS R. Diversity of the Fusarium graminearum species complex on French cereals. Eur. J. Plant Pathol. 138, 133, 2014.

75. POISSON M., HUGUET F., SAVATTIER A., BAKRILOGEAIS F., NARCISSE G. A new type of anticonvulsant, stiripentol. Pharmacological profile and neurochemical study. Arzneimittelforschung. 34 (2), 199, 1984.

76. KUBENA L.F., EDRINGTON T.S., HARVEY R.B., PHILLIPS T.D., SARR A.B., ROTTINGHAUS G.E. Individual and combined effects of fumonisin B1 present in Fusarium moniliforme culture material and diacetoxyscirpenol or ochratoxin A in turkey poults. Poult. Sci. 76 (2), 256, 1997. 